\title{
11. DISSECTING AN ACTIVE HYDROTHERMAL DEPOSIT: THE STRONTIUM AND OXYGEN ISOTOPIC ANATOMY OF THE TAG HYDROTHERMAL MOUND-ANHYDRITE ${ }^{1}$
}

\author{
Damon A.H. Teagle, ${ }^{2}$ Jeffrey C. Alt, ${ }^{2}$ Hitoshi Chiba, ${ }^{3}$ and Alex N. Halliday ${ }^{2}$
}

\begin{abstract}
Drilling at the Trans-Atlantic Geotraverse (TAG) active hydrothermal deposit on the Mid-Atlantic Ridge during Leg 158 of the Ocean Drilling Program recovered significant quantities of anhydrite from both the mound and the underlying mineralized stockwork zone. Anhydrite is present as a cement in disseminated sulfide breccias and in complex, multigeneration veins, up to $45 \mathrm{~cm}$ wide, at the upper levels of the deposit. It is a common late-stage vein and vug-filling mineral throughout the rest of the deposit, apart from a zone of anomalously low conductive heat flow that has been interpreted as a region of seawater entrainment into the mound.

The chemical and strontium- and oxygen-isotopic compositions of anhydrite are broadly similar throughout the mound, but are heterogeneous at a centimeter scale, with closely spaced samples displaying almost the full range of compositions. Values of ${ }^{87} \mathrm{Sr} /{ }^{86} \mathrm{Sr}$ indicate that most of the anhydrite formed from near-equal mixtures of seawater and black smoker fluids $(65 \% \pm$ $15 \%$ seawater). Assuming isotopic equilibrium, oxygen-isotopic compositions indicate that anhydrite precipitated at temperatures between $147^{\circ} \mathrm{C}$ and $270^{\circ} \mathrm{C}$ and require that seawater was conductively heated to between $100^{\circ}$ and $180^{\circ} \mathrm{C}$ before mixing and precipitation occurred.

Anhydrite from the TAG mound has an average Sr-Ca partition coefficient $K_{d} \approx 0.60 \pm 0.28(2 \sigma)$. This value is in agreement with the range of experimentally determined partition coefficients $\left(K_{d} \approx 0.27-0.73\right)$ and is similar to those calculated for anhydrite from active black smoker chimneys from $21^{\circ} \mathrm{N}$ on the East Pacific Rise.

The range of $\delta^{18} \mathrm{O}$ of TAG anhydrite brackets the value of seawater sulfate oxygen ( $9.34 \%$ ), which is known to be out of isotopic equilibrium with ocean-water oxygen at ocean temperatures. Anhydrite sulfate from active hydrothermal deposits, in isotopic equilibrium with fluids at approximately $200^{\circ} \mathrm{C}$, will dissolve back into the oceans during episodes of hydrothermal quiescence, without further modification because of the sluggish kinetics of sulfate-water oxygen-isotopic exchange at low temperatures. This provides an additional reservoir of isotopically light sulfate oxygen to the anhydrite that precipitates within the oceanic basement during hydrothermal recharge at the ridge.
\end{abstract}

\section{INTRODUCTION}

Recent drilling during Leg 158 of the Ocean Drilling Program penetrated the Trans-Atlantic Geotraverse (TAG) hydrothermal mound and recovered unique samples that allow the description of the subsurface anatomy of an active hydrothermal deposit and provide important constraints on fluid interactions and mineralization processes (Humphris et al., 1995; Humphris, Herzig, Miller, et al., 1996). One of the most surprising phenomena recovered in the Leg 158 drill cores was abundant anhydrite, precipitated in veins, vugs, and as a breccia cement within the mound and underlying stockwork. The large scale of precipitation of anhydrite within the TAG deposit attests to significant entrainment of seawater into and beneath the mound. This may greatly affect the short-term permeability and thermal structure and consequently influence the subsurface plumbing of the system. Mineral precipitation has been shown to modify white smoker fluid compositions (Tivey et al., 1995; Mills and Elderfield, 1995) and the chemistry of diffuse fluids (James and Elderfield, 1996).

The high concentration of sulfate in seawater and the retrograde solubility of anhydrite $\left(\mathrm{CaSO}_{4}\right)$ with increasing temperature mean that the precipitation of calcium sulfate plays a critical role in many aspects of submarine hydrothermal systems. The formation of anhydrite may affect crustal porosity and influence the general structure of axial hydrothermal systems (Woodruff and Shanks, 1988; Sleep,

'Herzig, P.M., Humphris, S.E., Miller, D.J., and Zierenberg, R.A. (Eds.), 1998. Proc. ODP, Sci. Results, 158: College Station, TX (Ocean Drilling Program).

${ }^{2}$ Department of Geological Sciences, 2534 C.C. Little Building, The University of Michigan, Ann Arbor, MI 48109-1063, U.S.A. Teagle: teagle@ umich.edu

${ }^{3}$ Department of Earth and Planetary Sciences, Kyushu University 33, Hakozaki, Fukuoka 812, Japan.
1991; Alt, 1995). Within the ocean crust, anhydrite precipitates in the basement near axis during hydrothermal recharge because of the interaction of heated seawater and basalt, and during subsurface mixing between seawater and upwelling black smoker-type fluids near the dike/volcanic transition (Alt et al., 1989; Sleep, 1991; Teagle et al., 1995). Anhydrite can also precipitate off-axis within the volcanic sequences of the upper crust as basement is buried by sediment and conductively reheated (Alt et al., 1989; Teagle et al., 1995). In contrast, the precipitation of anhydrite in black smoker chimneys results from the mixing of sulfate-rich seawater with hot $\left(>350^{\circ} \mathrm{C}\right)$ endmember hydrothermal fluids (e.g., Haymon and Kastner, 1981; Tivey, 1995).

Although fundamental uncertainties as to the behavior of sulfate in the oceanic hydrothermal systems still remain, the chemical and isotopic composition of anhydrite has been used as a powerful tracer of fluid evolution in oceanic hydrothermal systems (Teagle et al., 1995). In this paper, we present new strontium- and oxygen-isotopic analyses and cation concentrations $(\mathrm{Ca}, \mathrm{Sr}$, and $\mathrm{Mg}$ ) of anhydrite recovered during the drilling of the TAG hydrothermal deposit as well as from submersible expeditions to this site, in order to assess the physical, chemical, and fluid regimes responsible for the precipitation of anhydrite.

This paper briefly reviews the geological setting and structure of the TAG mound and underlying stockwork, and describes the distribution of anhydrite. Descriptions of the mineralogy and petrology of the host rocks (Honnorez et al., Chap. 18, this volume), whole-rock major- and trace-element chemistry (Humphris et al., Chap. 19, this volume), and the strontium- and oxygen-isotopic composition of whole rocks and silicate minerals (Alt and Teagle, Chap. 21, this volume; Teagle et al., Chap. 22, this volume) can be found in other companion papers to this manuscript. The reader is referred to those pa-

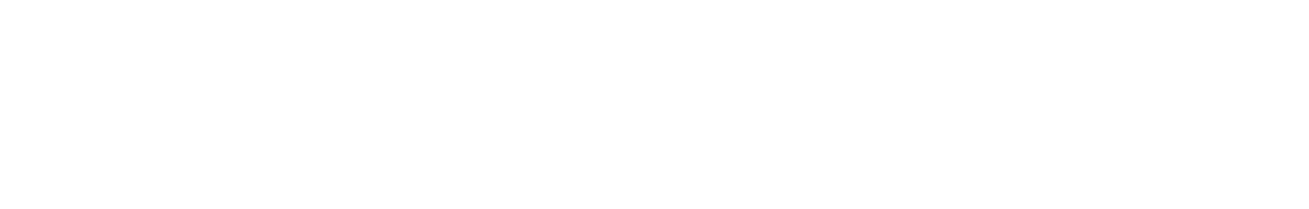


pers for detailed descriptions of the paragenetic sequence of wallrock alteration and mineralization within the TAG mound and stockwork.

\section{Geological Setting of the TAG Hydrothermal Mound, Mid-Atlantic Ridge}

Since the discovery of chemical anomalies in the seawater column, thought to result from hydrothermal venting along the Mid-Atlantic Ridge (Rona et al., 1975), the TAG hydrothermal field has been the principal locus of hydrothermal investigations in the Atlantic Ocean (Edmond et al., 1979; Campbell et al., 1988; Rona et al., 1986; Thompson et al., 1988; Elderfield et al., 1993; Tivey, 1995; Tivey et al., 1995). The geological setting of the TAG hydrothermal field has been recently reviewed in detail by Rona et al. (1993) and Humphris, Herzig, Miller, et al. (1996) and will be briefly summarized.

Low- and high-temperature hydrothermal activity and recently extinct relict sulfide deposits occupy a $5 \times 5-\mathrm{km}$ area on the eastern floor and rift valley of the Mid-Atlantic Ridge. The field is located at approximately $26^{\circ} 08^{\prime} \mathrm{N}$ at the middle of a 40-km-long, north-northeast-trending segment of ridge, one of 15 segments bounded by nontransform offsets between the Atlantis $\left(30^{\circ} \mathrm{N}\right)$ and the Kane $\left(24^{\circ} \mathrm{N}\right)$ Fracture Zones (Fig. 1).

The present site of active hydrothermal venting was discovered in 1985 (Rona et al., 1986) 1.5 to $2 \mathrm{~km}$ east of the ridge axis in water depths of 3630-3670 m. Here, a large sulfide mound, approximately $200 \mathrm{~m}$ in diameter and $35 \mathrm{~m}$ high, is the site of a variety of styles of focused high-temperature $\left(>350^{\circ} \mathrm{C}\right)$ hydrothermal fluid vents and lower-temperature diffuse flow. Assuming a linear spreading rate $(1.3 \mathrm{~cm} / \mathrm{yr}$; McGregor et al., 1977), the TAG hydrothermal mound is situated on crust of at least $100 \mathrm{ka}$.

The apparent longevity of hydrothermal venting at this site is evidenced by the size of the deposit, which requires an enduring interplay between volcanic and tectonic processes that have developed a basement permeability structure able to focus upwelling fluids at this site for a considerable time period. Radiometric dating of hydrothermal precipitates from the TAG mound suggest that hydrothermal activity has occurred at this site episodically for over 40,000-50,000 yr (Lalou et al., 1993, 1995, Chap. 9, this volume).

The active TAG mound is a steep-sided structure approximately $200 \mathrm{~m}$ in diameter with up to $50-\mathrm{m}$ relief. The mound is distinctly subcircular in plan view and surrounded by an apron, up to $100 \mathrm{~m}$ wide, of carbonate and metalliferous sediments (Fig. 1). Distinct platforms, at $3650 \mathrm{~m}$ below sea level (mbsl) and $3644 \mathrm{mbsl}$, suggest at least two phases of mound growth. The present location of concentrated high-temperature fluid venting is atop a conical structure, 10$15 \mathrm{~m}$ high and 20-30 $\mathrm{m}$ in diameter at the base, northwest of the center of the mound (Fig. 1). This Black Smoker Complex comprises a cluster of chimneys (up to $15 \mathrm{~m}$ high) that vent fluids up to $363^{\circ} \pm$ $3^{\circ} \mathrm{C}$ (Edmond et al., 1995). The lower platform is approximately 100 $\mathrm{m}$ wide, with an irregular surface comprising sulfide debris, talus, standing and toppled chimneys, and iron oxide crusts. Low-temperature diffuse flow occurs across this platform, though it is most concentrated near the central black smoker edifice. In the southeast quadrant of the mound, a community of more than 10 squat, bulbous chimneys (the "Kremlin" area; Thompson et al., 1988) issue $260^{\circ}$ to $300^{\circ} \mathrm{C}$ white smoker fluids.

Conductive heat-flow measurements across the mound and its surrounds (Becker and Von Herzen, 1996) are generally high, though measurements are commonly complicated by the upward passage of diffuse hydrothermal fluids through the sediment cover. Elevated heat flow clearly indicates that mound-related heat- and fluid-flow processes extend in the subsurface beyond the extent of the mound. However, a swath of very low heat flow $\left(<20 \mathrm{~mW} / \mathrm{m}^{2}\right)$ on the western section of the main platform of the TAG mound, within 20 to $50 \mathrm{~m}$ of the Black Smoker Complex, indicates the local recharge of ocean bottom water into the mound (Fig. 1; Becker and Von Herzen, 1996).

\section{The Internal Structure of the TAG Mound and Stockwork: Distribution of Alteration Assemblages and Anhydrite}

Seventeen holes were drilled at five different locations (TAG 15; see Figs. 1 and 2) on the TAG mound in order to define the subsurface nature and lateral heterogeneity of the active mound and its underlying zone of stockwork alteration and mineralization. Shipboard scientists classified 20 different rock types in the TAG drill core (Humphris, Herzig, Miller, et al., 1996) and consequently the stratigraphy is complicated at a fine scale. At a larger scale, however, the mound can be divided into relatively few lithologic zones and a simplified stratigraphy for the hydrothermal deposits is summarized in Figure 2.

The uppermost 5-20 m of the mound consists mainly of pyrite breccias that contain clasts of pyrite or massive pyrite in a pyrite matrix. These breccias also contain local concentrations of chalcopyrite and sphalerite, plus common minor quartz and/or anhydrite in the matrix. Near the Black Smoker Complex in the central and northern parts of the mound (TAG- 1 and TAG-5 areas), the pyrite breccias are underlain by a 10- to 15-m-thick anhydrite-rich zone. This zone consists of mainly pyrite-anhydrite breccias that contain clasts of pyrite \pm siliceous material (quartz + pyrite, silicified basalt fragments, clasts of other quartz-rich breccias) in a matrix containing greater than $10 \%$ anhydrite. The massive pyrite breccias and anhydrite-rich rocks are in turn underlain by pyrite-silica breccias, which consist of clasts of pyrite, quartz + pyrite, and/or siliceous material, in a quartz-rich $(>10 \%)$ matrix. Variable proportions of silicified wallrock breccias occur with pyrite-silica breccias below 25-35 mbsf at TAG-1, TAG4, and TAG-5. Altered and silicified basalt clasts become much more abundant in the pyrite-silica breccias below this depth, which marks the top of the stockwork zone.

The stockwork feeder zone at TAG is zoned vertically and exhibits lateral variations. The siliceous stockwork begins at about 25-35 mbsf in the pyrite-silica breccias and continues downward in the silicified wallrock breccias, which contain the quartz + paragonite + pyrite assemblage (Fig. 2). Silicified wallrock breccias of the stockwork at TAG-1 and TAG-2 are siliceous, whereas those at TAG-4 and TAG-5, although they contain the same phases, are more pyritic. Massive pyrite is common, cementing and partly replacing altered basalt clasts at both sites, and at TAG-4 the clasts are noticeably less silicified and may represent a talus pile. Below $101 \mathrm{mbsf}$, the rocks of the "sericitic" or paragonitic stockwork are less silicified, and contain the assemblage paragonite + quartz + pyrite. At $111 \mathrm{mbsf}$, the chloritic stockwork begins, with chlorite + quartz + pyrite and paragonite + quartz + pyrite assemblages.

Basaltic basement penetrated at TAG-4 and in Hole 957B at TAG-2 constrains the width of the TAG stockwork near the surface to about $80-90 \mathrm{~m}$ (Fig. 2). At TAG-4, the basement consists of dark gray basalt with centimeter-sized green chloritized halos. The basement at TAG-2 consists of a 30 -cm section of hydrothermally altered pillow breccia overlying dark gray, slightly altered basalt.

\section{Distribution of Anhydrite in the TAG Hydrothermal Mound}

Previous to drilling at the TAG hydrothermal mound on Leg 158, anhydrite had been observed and collected by submersible from the surface of the mound (Rona et al., 1993; Masuda et al, 1995; Mills and Elderfield, 1995). Most of the anhydrite observed on top of the mound is associated with the central edifice of the Black Smoker Complex, which is constructed of massive chalcopyrite and pyrite with subsidiary anhydrite precipitating at the active vents or in slumped blocks. Large blocks of coarse-grained anhydrite up to several meters thick crop out on the sides and at the base of the conical edifice. These blocks are undergoing corrosion by ambient seawater, exposing abundant disseminated grains of chalcopyrite and pyrite. The top of the active Black Smoker Complex, where visible, is coated with massive chalcopyrite and pyrite, intergrown with corroded thick 

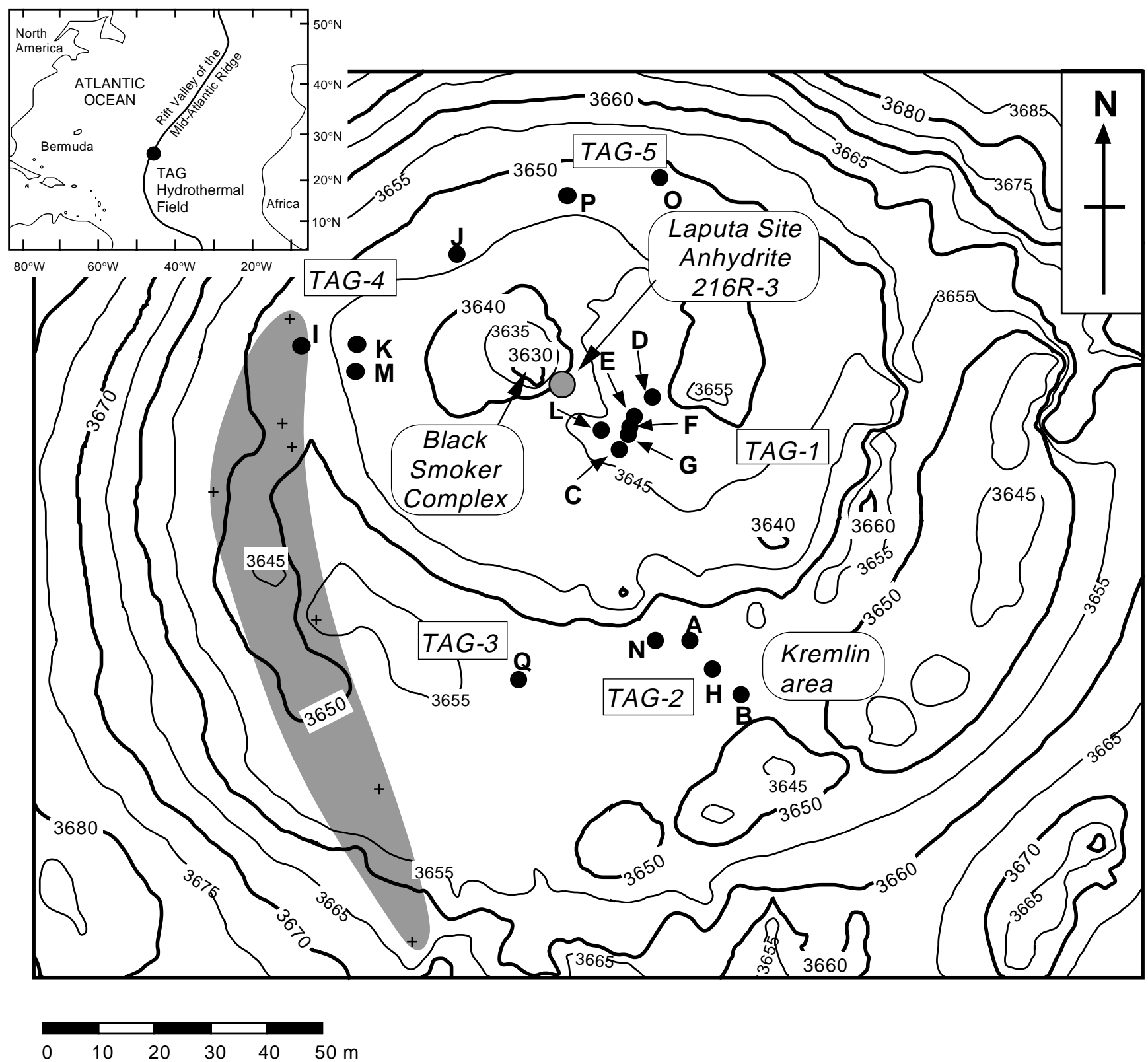

Figure 1. Detailed bathymetry of the TAG mound and locations of Leg 158 drill holes at Site 957 (solid circles). Drill holes are grouped into five areas (TAG-1 through TAG-5). See text for detailed descriptions. Bathymetric contour interval is $5 \mathrm{~m}$ (after Humphris, Herzig, Miller, et al., 1996). Inset shows the location of the TAG mound in relation to the Mid-Atlantic Ridge. The TAG active mound is positioned on $100 \mathrm{ka}$ crust to the east of the axis of spreading. Relict sulfide deposits (Alvin and Mir) and low-temperature hydrothermal fields are located to the north and east of the active mound. Stippled region to the west of the main Black Smoker Complex indicates the north-south-trending zone of anomalously low conductive heat flow $\left(<20 \mathrm{~mW} / \mathrm{m}^{2}\right)$, potentially an area of local recharge of ocean bottom water into the mound (Becker and Von Herzen, 1996).

layers $(>1 \mathrm{~m})$ of coarse granular anhydrite containing disseminated pyrite (Rona et al., 1993).

The lower platform of the TAG mound comprises an irregular surface of sulfide talus and debris ranging in size from boulders to fine sand, toppled and standing chimneys, and intact Fe oxide crusts. Diffuse hydrothermal venting, up to $50^{\circ} \mathrm{C}$, is common across the mound, though it is most intense near the base of the Black Smoker Complex. Anhydrite does not crop out on the lower platform except at the base of the central black smoker edifice. Mills and Elderfield (1995) sampled grains of anhydrite from the base of a bulbous white smoker chimney from the Kremlin area (TAG-2). Anhydrite has not been observed from around the margins of the mound.
Although the involvement of anhydrite in chimney construction is well established (Haymon, 1983), the larger role that the precipitation of anhydrite plays in mound construction and mass wasting was not previously recognized until drilling on Leg 158 penetrated the interior of the TAG hydrothermal deposit. Anhydrite is a common breccia cement and late-stage vein and cavity filling throughout most of the mound and the underlying stockwork (Fig. 2; Humphris et al., 1995; Humphris, Herzig, Miller, et al., 1996).

A 10- to 15-m-thick anhydrite-rich zone underlies the cap of massive pyrite and pyrite breccias that form the uppermost part of the mound near the Black Smoker Complex in the central and northern parts of the mound (TAG-1 and TAG-5 areas). Anhydrite breccias 
Figure 2. Northwest-southeast cross section showing the generalized lithology and stratigraphy of the TAG mound and stockwork. The stratigraphy of TAG-5, which lies to the north of the Black Smoker Complex (see Fig. 1), has been projected onto the cross section. See text for details. Overlaid on this cross section is the distribution of anhydrite as both breccia cements and as vein and vug-filling minerals throughout the mound. Note the absence of anhydrite from the TAG- 4 site.

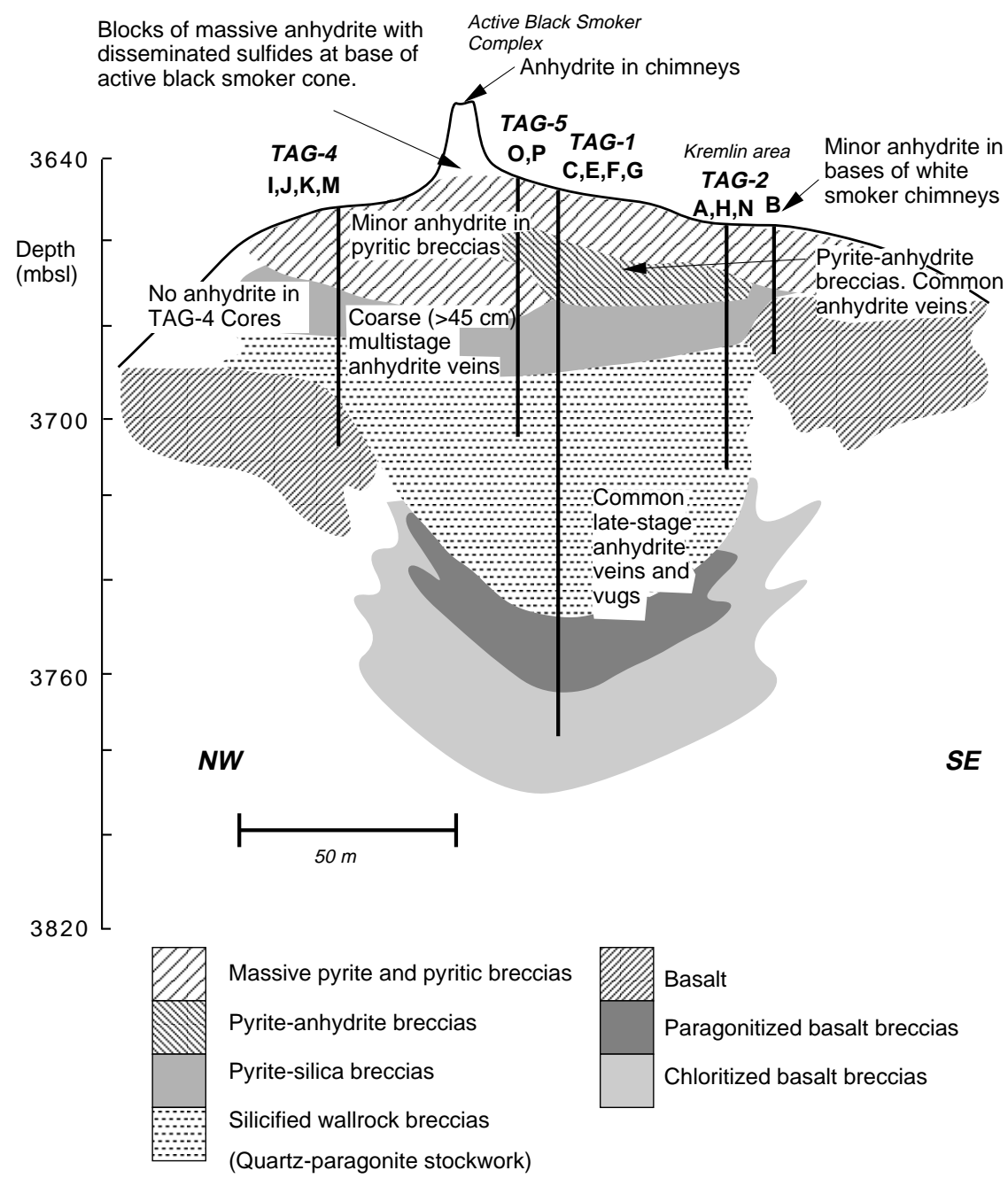

would be expected (e.g., Bischoff and Seyfried, 1978). This coincides with the swath of low measured conductive heat flow across the western shoulder of the TAG mound (Becker and Von Herzen, 1996), indicating that there is active entrainment of seawater and cooling of the mound in this region.

\section{SAMPLING AND ANALYTICAL METHODS}

Twenty anhydrite samples have been selected from the TAG-1 (Holes 957C and 957E) and TAG-2 (Hole 957H) drill sites in order to define the variation in composition throughout the mound as well as the heterogeneity at the hand-specimen scale (Table 1). Samples were separated from veins and vugs from the whole rock samples using a steel probe and then picked by hand under microscope to minimize contamination by either silicate or sulfide minerals. The pure mineral was then split for separate strontium- and oxygen-isotope composition determinations. Cation concentrations were determined on a split of the strontium aliquot after the anhydrite had been completely dissolved.

Three analyses were made of Sample 158-957C-11N-1 (Piece $3 \mathrm{~K})$. This specimen comprises part of a complex multistage, composite anhydrite vein. Banded anhydrite fills open spaces and multiple generations of anhydrite veins cut brecciated anhydrite clasts. The sample contains only minor chalcopyrite and pyrite disseminated in gray bands in anhydrite and minor fine-grained iron oxides (see Fig. 3 ). Adjacent interstitial and vein anhydrite were analyzed from a pyrite-silica breccia from Sample 158-957C-11N-3 (Piece 10B). Two 
Table $1 .{ }^{87} \mathrm{Sr} /{ }^{86} \mathrm{Sr}, \delta^{18} \mathrm{O}$, and cation concentrations of anhydrite from Site 957.

\begin{tabular}{|c|c|c|c|c|c|c|c|c|c|c|c|c|c|}
\hline $\begin{array}{l}\text { Core, section, } \\
\text { interval }(\mathrm{cm})\end{array}$ & $\begin{array}{l}\text { Depth } \\
(\mathrm{mbsf})\end{array}$ & Comment & ${ }^{87} \mathrm{Sr} /{ }^{86} \mathrm{Sr} \pm 2 \mathrm{~s}$ & $\begin{array}{c}\mathrm{Sr} / \mathrm{Ca} \\
(\mathrm{mmol} / \mathrm{mol})\end{array}$ & $\begin{array}{c}\mathrm{Mg} / \mathrm{Ca} \\
(\mathrm{mmol} / \mathrm{mol})\end{array}$ & $\begin{array}{c}\mathrm{Sr} \\
(\mathrm{ppm})\end{array}$ & $\begin{array}{c}\mathrm{Mg} \\
(\mathrm{ppm})\end{array}$ & $\begin{array}{l}\delta^{18} \mathrm{O} \\
(\% o)\end{array}$ & $\mathrm{X}^{\text {seawater }}$ & $K_{d}$ & $\begin{array}{l}\text { Calc } \\
\mathrm{T}\left({ }^{\circ} \mathrm{C}\right)\end{array}$ & $\begin{array}{l}\mathrm{T}\left({ }^{\circ} \mathrm{C}\right) \\
(0 \%)\end{array}$ & $\begin{array}{l}\mathrm{T}\left({ }^{\circ} \mathrm{C}\right) \\
\text { mixed }\end{array}$ \\
\hline $\begin{array}{l}\text { Surface sample } \\
\quad 216 \mathrm{R}-3\end{array}$ & 0.00 & Surface & $0.707061 \pm 0.000010$ & 3.31 & 1.85 & 2131 & 330 & $8.5 \dagger$ & 65 & 0.63 & 130 & 220 & 231 \\
\hline TAG-1 (Central) & & & & & & & & & & & & & \\
\hline $\begin{array}{l}\text { 158-957C- } \\
\text { 7N-1, 95-95 (Piece 8B) } \\
11 \mathrm{~N}-1,125-125 \text { (Piece 3K) } \\
11 \mathrm{~N}-1,126-126 \text { (Piece 3K) } \\
11 \mathrm{~N}-1,129-129 \text { (Piece 3K) } \\
11 \mathrm{~N}-1,131-134 \text { (Piece 3K) } \\
\text { 11N-3, 38-40 (Piece 5A) } \\
\text { 11N-3, 66-68 (Piece 6) } \\
\text { 11N-3, 121-123 (Piece 10B) } \\
\text { 11N-3, 121-123 (Piece 10B) } \\
\text { 14N-2, 7-10 (Piece 1B) } \\
\text { 16N-2, 102-105 (Piece 9D) }\end{array}$ & $\begin{array}{l}20.30 \\
31.95 \\
31.96 \\
31.99 \\
32.01 \\
33.99 \\
34.25 \\
34.82 \\
34.82 \\
41.10 \\
48.50\end{array}$ & $\begin{array}{l}\text { Interstitial } \\
\text { Vein }\end{array}$ & $\begin{array}{l}0.707102 \pm 0.000010 \\
0.706352 \pm 0.000008 \\
0.706734 \pm 0.000010 \\
0.707333 \pm 0.000011 \\
0.706370 \pm 0.000011 \\
0.706695 \pm 0.000010 \\
0.706695 \pm 0.000008 \\
0.707284 \pm 0.000010 \\
0.706845 \pm 0.000010 \\
0.706653 \pm 0.000010 \\
0.706886 \pm 0.000008\end{array}$ & $\begin{array}{l}2.73 \\
2.66 \\
2.80 \\
4.07 \\
2.45 \\
2.39 \\
2.95 \\
2.50 \\
2.47 \\
2.21 \\
2.23\end{array}$ & $\begin{array}{l}1.43 \\
0.15 \\
0.40 \\
0.16 \\
0.08 \\
0.48 \\
0.23 \\
0.20 \\
0.36 \\
4.97 \\
0.19\end{array}$ & $\begin{array}{l}1757 \\
1713 \\
1804 \\
2618 \\
1575 \\
1538 \\
1896 \\
1608 \\
1593 \\
1424 \\
1437\end{array}$ & $\begin{array}{r}255 \\
26 \\
72 \\
29 \\
14 \\
86 \\
40 \\
35 \\
64 \\
887 \\
34\end{array}$ & $\begin{array}{c}8.2 \dagger \\
7.0 \dagger \\
8.2 \dagger \\
9.1 \dagger \\
8.8 \\
8.2 \\
9.0 \\
10.0 \\
9.5 \\
7.8 \dagger \\
8.8 \dagger\end{array}$ & $\begin{array}{l}65 \\
52 \\
69 \\
59 \\
52 \\
58 \\
58 \\
69 \\
61 \\
57 \\
61\end{array}$ & $\begin{array}{l}0.51 \\
0.57 \\
0.56 \\
0.73 \\
0.52 \\
0.48 \\
0.60 \\
0.45 \\
0.49 \\
0.45 \\
0.44\end{array}$ & $\begin{array}{l}127 \\
175 \\
113 \\
151 \\
177 \\
154 \\
154 \\
116 \\
144 \\
156 \\
141\end{array}$ & $\begin{array}{l}225 \\
250 \\
225 \\
209 \\
215 \\
225 \\
212 \\
194 \\
202 \\
233 \\
214\end{array}$ & $\begin{array}{l}237 \\
231 \\
218 \\
240 \\
270 \\
240 \\
225 \\
203 \\
214 \\
249 \\
227\end{array}$ \\
\hline $\begin{array}{l}\text { 158-957E- } \\
\text { 7R-1, 14-18 (Piece 3) } \\
\text { 8R-1, 15-20 (Piece 3) } \\
\text { 14R-1, 41-44 (Piece 10) } \\
\text { 15R-1, 15-19 (Piece 4) } \\
\text { 18R-1, 20-24 (Piece 4) } \\
\text { 18R-1, 20-24 (Piece 4) }\end{array}$ & $\begin{array}{r}68.44 \\
72.95 \\
101.90 \\
106.75 \\
120.90 \\
120.90\end{array}$ & $\begin{array}{l}\text { Sugary } \\
\text { Tabular }\end{array}$ & $\begin{array}{l}0.706941 \pm 0.000011 \\
0.706795 \pm 0.000010 \\
0.708545 \pm 0.000011 \\
0.708634 \pm 0.000010 \\
0.706601 \pm 0.000010 \\
0.708628 \pm 0.000010\end{array}$ & $\begin{array}{l}2.27 \\
2.58 \\
7.04 \\
5.79 \\
3.64 \\
4.05\end{array}$ & $\begin{array}{l}3.58 \\
5.90 \\
0.10 \\
0.78 \\
0.29 \\
2.61\end{array}$ & $\begin{array}{l}1458 \\
1659 \\
4533 \\
3727 \\
2341 \\
2609\end{array}$ & $\begin{array}{r}640 \\
1054 \\
18 \\
139 \\
52 \\
466\end{array}$ & $\begin{array}{l}13.6 \\
13.2\end{array}$ & $\begin{array}{l}62 \\
60 \\
90 \\
91 \\
56 \\
91\end{array}$ & $\begin{array}{l}0.44 \\
0.51 \\
0.98 \\
0.79 \\
0.75 \\
0.55\end{array}$ & $\begin{array}{r}138 \\
147 \\
39 \\
33 \\
160 \\
34\end{array}$ & $\begin{array}{l}146 \\
150\end{array}$ & $\begin{array}{l}147 \\
152\end{array}$ \\
\hline TAG-2 (Kremlin) & & & & & & & & & & & & & \\
\hline $\begin{array}{l}\text { 158-957H- } \\
\text { 5N-2, 10-12 (Piece 1B) } \\
5 \mathrm{~N}-2,38-40 \text { (Piece 1D) } \\
5 \mathrm{~N}-2,79-84 \text { (Piece 3C) }\end{array}$ & $\begin{array}{l}27.75 \\
27.85 \\
28.39\end{array}$ & & $\begin{array}{l}0.707648 \pm 0.000010 \\
0.707948 \pm 0.000010 \\
0.707272 \pm 0.000011\end{array}$ & $\begin{array}{l}3.86 \\
4.31 \\
3.56\end{array}$ & $\begin{array}{l}0.23 \\
0.23 \\
0.12\end{array}$ & $\begin{array}{l}2484 \\
2775 \\
2290\end{array}$ & $\begin{array}{l}40 \\
40 \\
22\end{array}$ & $\begin{array}{l}10.9 \\
10.2 \\
10.1\end{array}$ & $\begin{array}{l}75 \\
80 \\
68\end{array}$ & $\begin{array}{l}0.66 \\
0.69 \\
0.65\end{array}$ & $\begin{array}{r}93 \\
74 \\
116\end{array}$ & $\begin{array}{l}180 \\
191 \\
192\end{array}$ & $\begin{array}{l}187 \\
196 \\
201\end{array}$ \\
\hline
\end{tabular}

Notes: * surface anhydrite sample from Masuda et al. (1995). $\dagger=\delta^{18} \mathrm{O}$ analyzed at Kyushu University following methods described in Chiba et al., (Chap. 6 , this volume); other $\delta^{18} \mathrm{O}$ analyses conducted at the University of Michigan. $\mathrm{Sr}$ and $\mathrm{Mg}$ concentrations (in ppm) calculated assuming stoichiometric $\mathrm{Ca}$ in anhydrite and $\mathrm{Sr} / \mathrm{Ca}$ and $\mathrm{Mg} / \mathrm{Ca}$ ratios of dissolved sample. Proportion of seawater ( $\mathrm{X}^{\text {seawater}}$ ) calculated from measured ${ }^{87} \mathrm{Sr} /{ }^{86} \mathrm{Sr}$ assuming mixing between seawater $\left({ }^{87} \mathrm{Sr} /{ }^{86} \mathrm{Sr}=0.70918 ; \mathrm{Hodell}\right.$ et al., $\left.1991 ; \mathrm{Sr} \approx 87 \mathrm{mM}\right)$ and TAG end-member black smoker fluids ${ }^{87} \mathrm{Sr} /{ }^{86} \mathrm{Sr}=0.7038$; Edmond et al., 1995; Teagle et al., Chap. 22 , this volume; $\left.\mathrm{Sr}=103 \mathrm{mM}\right) . K_{d}$ calculated from $\mathrm{Sr} / \mathrm{Ca}$ and ${ }^{87} \mathrm{Sr} /{ }^{86} \mathrm{Sr}$ ratio of anhydrite using Equation 1 . The temperature of this mixture was calculated assuming mixing of end-members in the proportions suggested by the measured ${ }^{87} \mathrm{Sr} /{ }^{86} \mathrm{Sr}$ for black smoker fluids at $363^{\circ} \mathrm{C}$ and seawater at $2^{\circ} \mathrm{C}$. A constant specific heat capacity is assumed and the effects of conductive heating or cooling of the solutions is ignored. Temperatures are also calculated from the measured oxygen-isotope composition assuming equilibrium oxygen exchange between fluid and anhydrite. Temperatures are calculated for precipitation from seawater $\left(0 \%\right.$ ) and for a seawater-hydrothermal fluid mixture in the proportions indicated by the measured ${ }^{87} \mathrm{Sr} /{ }^{86} \mathrm{Sr}$. End-member black smoker fluids from TAG have a $\delta^{18} \mathrm{O} \approx 1.7 \%$ o (Shanks et al., 1995).

generations of anhydrite were taken from Sample 158-957E-18R-1 (Piece 4$)$ in which a thick $(\sim 1 \mathrm{~cm})$ pyrite-anhydrite vein cuts across chloritized basaltic breccia (see Teagle et al., Chap. 22, this volume). One analysis is of closely intergrown and equigranular anhydrite with a sugary texture that is typical of most of the anhydrite in this specimen, but the second analysis is of a late generation of anhydrite that occurs as delicate, clear tabular crystals.

One surface anhydrite sample collected by submersible has been analyzed (Sample 216R-3; Masuda et al., 1995). This sample is from a 4.4-kg anhydrite block with disseminated chalcopyrite, and minor pyrite, pyrrhotite, and gypsum, that was collected from an active vent on the southeast margin of the top of the Black Smoker Complex ("Laputa" site of Masuda et al., 1995; see Fig. 1)

Strontium-isotopic compositions were determined by thermal ionization mass spectrometry in the Radiogenic Isotope Geochemistry Laboratory at the University of Michigan. Approximately 10 to 20 $\mathrm{mg}$ of selected anhydrite was ground in agate with $1 \mathrm{~mL}$ super-deionized (SDI) water. Samples were diluted to $2-3 \mathrm{~mL}$ with $\mathrm{SDI}_{2} \mathrm{O}$, and a drop of $6 \mathrm{~N} \mathrm{HCl}$ added. They were then left on a hot plate in a capped Savilex beaker until dissolution was complete. Samples were evaporated to incipient dryness and then taken up in $0.2 \mathrm{~mL}$ of $3 \mathrm{M}$ $\mathrm{HNO}_{3}$ before loading on fresh, cleaned Sr-Spec columns with a resin bed volume of $\sim 0.07 \mathrm{~mL}$. Major elements were eluted with $1 \mathrm{~mL}$ of $3 \mathrm{M} \mathrm{HNO}_{3}$ before collecting $\mathrm{Sr}$ in $1 \mathrm{~mL}$ of $\mathrm{H}_{2} \mathrm{O}$.

Strontium-isotopic compositions $\left({ }^{87} \mathrm{Sr} /{ }^{86} \mathrm{Sr}\right)$ were determined by loading on single Re filaments with a $\mathrm{TaCl}_{5}$ solution and $5 \%$ phosphoric acid. Samples were analyzed on a V.G. Sector-II multiple collector mass spectrometer ("Damian"), using a $2.0 \pm 0.2 \times 10^{-11} \mathrm{~A}$ ion beam with at least 200 ratios collected in a multidynamic mode and normalized to ${ }^{86} \mathrm{Sr} /{ }^{88} \mathrm{Sr}=0.1194$. For the period of the analysis (January-April 1996) NIST SRM 987 gave ${ }^{87} \mathrm{Sr} /{ }^{86} \mathrm{Sr}=0.710214 \pm$ $0.000018(2 \sigma, \mathrm{n}=20)$. Ratios reported in Table 1 have been normalized to NIST SRM $987{ }^{87} \mathrm{Sr} /{ }^{86} \mathrm{Sr}=0.710237$ for consistency with data reported in Teagle et al. (Chap. 22, this volume). Full analytical procedural blanks were $<50 \mathrm{pg}$ for $\mathrm{Sr}$.

Oxygen-isotope measurements were made in the Stable Isotope Laboratory at the University of Michigan and the Department of Earth and Planetary Sciences, Kyushu University (see methods of Chiba et al., Chap. 6, this volume). For samples analyzed at Michigan (Table 1) oxygen was extracted from pure anhydrite separates by reaction with $\mathrm{ClF}_{3}$ and converted to $\mathrm{CO}_{2}$ gas using the technique of Pickthorn and O'Neil (1985). Oxygen isotope ratios were then analyzed on a Finnigan Delta-S mass spectrometer. Results are reported as $\delta$ notation relative to standard mean ocean water (SMOW; Craig, 1961), where:

$$
\delta^{18} \mathrm{O}(\%)=\left[\frac{\left({ }^{18} \mathrm{O} /{ }^{16} \mathrm{O}\right)_{\text {Sample }}-\left({ }^{18} \mathrm{O} /{ }^{16} \mathrm{O}\right)_{\text {SMOW }}}{\left({ }^{18} \mathrm{O} /{ }^{16} \mathrm{O}\right)_{\text {SMOW }}}\right] \times 1000
$$

Repeated extractions and measurements of samples and standards were reproducible within $\pm 0.5 \%$ o.

Splits of the dissolved solution used for ${ }^{87} \mathrm{Sr} /{ }^{86} \mathrm{Sr}$ were analyzed for their major and trace cation concentrations $(\mathrm{Ca}, \mathrm{Mg}, \mathrm{Sr})$ determined simultaneously by inductively coupled plasma atomic emission spectroscopy (ICP-AES) using a Leeman Labs Plasma-Spec III at the University of Michigan, following procedures described by Carpenter et al. (1991).

\section{RESULTS}

Sample descriptions and analytical results are presented in Table 1. Molar $\mathrm{Sr} / \mathrm{Ca}$ and $\mathrm{Mg} / \mathrm{Ca}$ ratios were calculated directly from the analyzed solution data. Concentrations of $\mathrm{Sr}$ and $\mathrm{Mg}$ (in ppm) have been calculated from the analyzed ratios against $\mathrm{Ca}$, assuming that $\mathrm{Ca}$ is present in a stoichiometric amount. 
Figure 3. Photograph of Sample 158-957H-11N-3 (Piece 3) showing the complex intergrowth of multiple generations of anhydrite precipitation and the analytical results of three subsamples. Note the large range in ${ }^{87} \mathrm{Sr} /{ }^{86} \mathrm{Sr}$ and $\delta^{18} \mathrm{O}$.

Figure 3 illustrates the fine-scale heterogeneity of anhydrite chemistry in a sample of a multigeneration anhydrite vein (Sample 158-957C-11N-1, [Piece 3K]). Significant differences exist in both oxygen- and strontium-isotopic compositions between different growth stages and morphologies of anhydrite precipitation This heterogeneity is even more pronounced in samples from Sample 158957E-18R-1 (Piece 4; see Table 1) in which the early generation of equigranular anhydrite that comprises the bulk of the anhydrite has a ${ }^{87} \mathrm{Sr} /{ }^{86} \mathrm{Sr} \approx 0.7066$ and the later, fine tabular anhydrite has a highly elevated isotopic composition $\left({ }^{87} \mathrm{Sr} /{ }^{86} \mathrm{Sr} \approx 0.7086\right)$ close to modern seawater $\left({ }^{87} \mathrm{Sr} /{ }^{86} \mathrm{Sr} \approx 0.70918\right.$; Hodell et al., 1991).

${ }^{87} \mathrm{Sr} /{ }^{86} \mathrm{Sr}, \delta^{18} \mathrm{O}, \mathrm{Sr} / \mathrm{Ca}$, and $\mathrm{Mg} / \mathrm{Ca}$ analytical results are plotted against depth in a composite section for sites TAG-1 and -2 in Figure 4. Also shown in Figure 4 is the distribution of whole-rock ${ }^{87} \mathrm{Sr} /{ }^{86} \mathrm{Sr}$ for quartz-pyrite ( \pm chlorite \pm paragonite) breccias and altered rocktypes from the TAG mound and stockwork (after Teagle et al., Chap. 22 , this volume). Most anhydrite samples from TAG-1 fall in the range of ${ }^{87} \mathrm{Sr} /{ }^{86} \mathrm{Sr} \approx 0.7064-0.7073$, compositions between end-member black smoker fluids $\left({ }^{87} \mathrm{Sr} /{ }^{86} \mathrm{Sr} \approx 0.7038\right.$; Edmond et al., 1995; Teagle et al., Chap. 22, this volume) and seawater. If anhydrite is the product of simple mixing, these data suggest interaction between near-equal proportions of seawater and hydrothermal fluids (see Table 1). Significantly, there are no anhydrites with low ${ }^{87} \mathrm{Sr} /{ }^{86} \mathrm{Sr}$ ratios $(<0.7038)$ that might result from the interaction between basalt and conductively heated seawater as are present in the volcanic rocks and sheeted dikes of Hole 504B (Teagle et al., 1995). This indicates that anhydrite precipitation via such interaction is not an important process within the TAG deposit.

Three analyses from deep in the TAG-1 section yield much higher Sr-isotopic compositions $\left({ }^{87} \mathrm{Sr} /{ }^{86} \mathrm{Sr} \approx 0.7085-0.7086\right)$, approaching that of seawater. However, large differences in isotopic compositions are displayed by early- and late-stage anhydrite at the base of the TAG-1 section (Sample 158-957E-18R-1, [Piece 4]; Table 1). The early generation of anhydrite in this sample, which is representative of most of the deep anhydrite, yields an intermediate ${ }^{87} \mathrm{Sr} /{ }^{86} \mathrm{Sr}$ ratio within the range of samples from higher in the stockwork and mound.
Analyses from TAG-2 have a limited range of Sr-isotopic compositions and are at the high end of the range displayed by the bulk of the TAG-1 anhydrites.

Bulk-rock samples of altered basalts and mineralized breccias from the stockwork and mound that have high $\mathrm{Ca}$ and $\mathrm{Sr}$ contents and elevated ${ }^{87} \mathrm{Sr} /{ }^{86} \mathrm{Sr}$ ratios (Fig. 4) most probably reflect minor $(\approx 5 \%)$ contamination by anhydrite (Teagle et al., Chap. 22, this volume; Humphris et al., Chap. 19, this volume). The surface sample, Sample $216 \mathrm{R}-3$, has an ${ }^{87} \mathrm{Sr} /{ }^{86} \mathrm{Sr}$ of 0.7071 similar to anhydrite taken from the subsurface, but significantly higher than other compositions reported for submersible-collected surface samples from black and white smokers $\left({ }^{87} \mathrm{Sr} /{ }^{86} \mathrm{Sr} \approx 0.7051-0.7067\right)$ reported by Mills and Elderfield (1995).

Anhydrite from the surface and subsurface shows a limited range in $\delta^{18} \mathrm{O}(\approx 7 \%$ o-10\%o $)$ All samples are significantly shifted from the oxygen-isotopic composition of seawater $\left(\delta^{18} \mathrm{O} \approx 9.34\right)$, to both higher and lower values, indicating that some isotopic exchange has occurred between dissolved sulfate and the fluid during or prior to the precipitation of anhydrite. Two samples from deep in the TAG-1 drill holes have high $\delta^{18} \mathrm{O}(13.2 \%, 13.6 \%)$, significantly heavier than samples from higher in the stockwork and mound. These deeper samples also have atypical ${ }^{87} \mathrm{Sr} /{ }^{86} \mathrm{Sr}$ ratios that are near seawater.

Figure 4 shows measured $\mathrm{Sr} / \mathrm{Ca}$ ratios for anhydrite and the range of predicted $\mathrm{Sr} / \mathrm{Ca}$ ratios for anhydrite precipitated from both seawater and TAG black smoker fluids using experimentally determined partition coefficients (Shikazono and Holland, 1983; Berndt et al., 1988). Most data fall within the predicted range, indicating that the recommended partition coefficients are appropriate and also that the composition of anhydrite within the mound and stockwork can generally be explained as precipitating from simple mixtures of hydrothermal fluids and seawater, without invoking complex fluid evolutions. The $\mathrm{Sr} / \mathrm{Ca}$ value of the surface sample, Sample 216R-3, falls within the range of the subsurface data.

The significance of the $\mathrm{Mg} / \mathrm{Ca}$ data presented in Figure 4 is not clear. $\mathrm{Mg} / \mathrm{Ca}$ values are generally low $\left(\mathrm{Mg} / \mathrm{Ca}<1 \times 10^{-3} \mathrm{mmol} / \mathrm{mol}\right)$, indicating very low $\mathrm{Mg}$ contents in most samples. There is no obvi- 


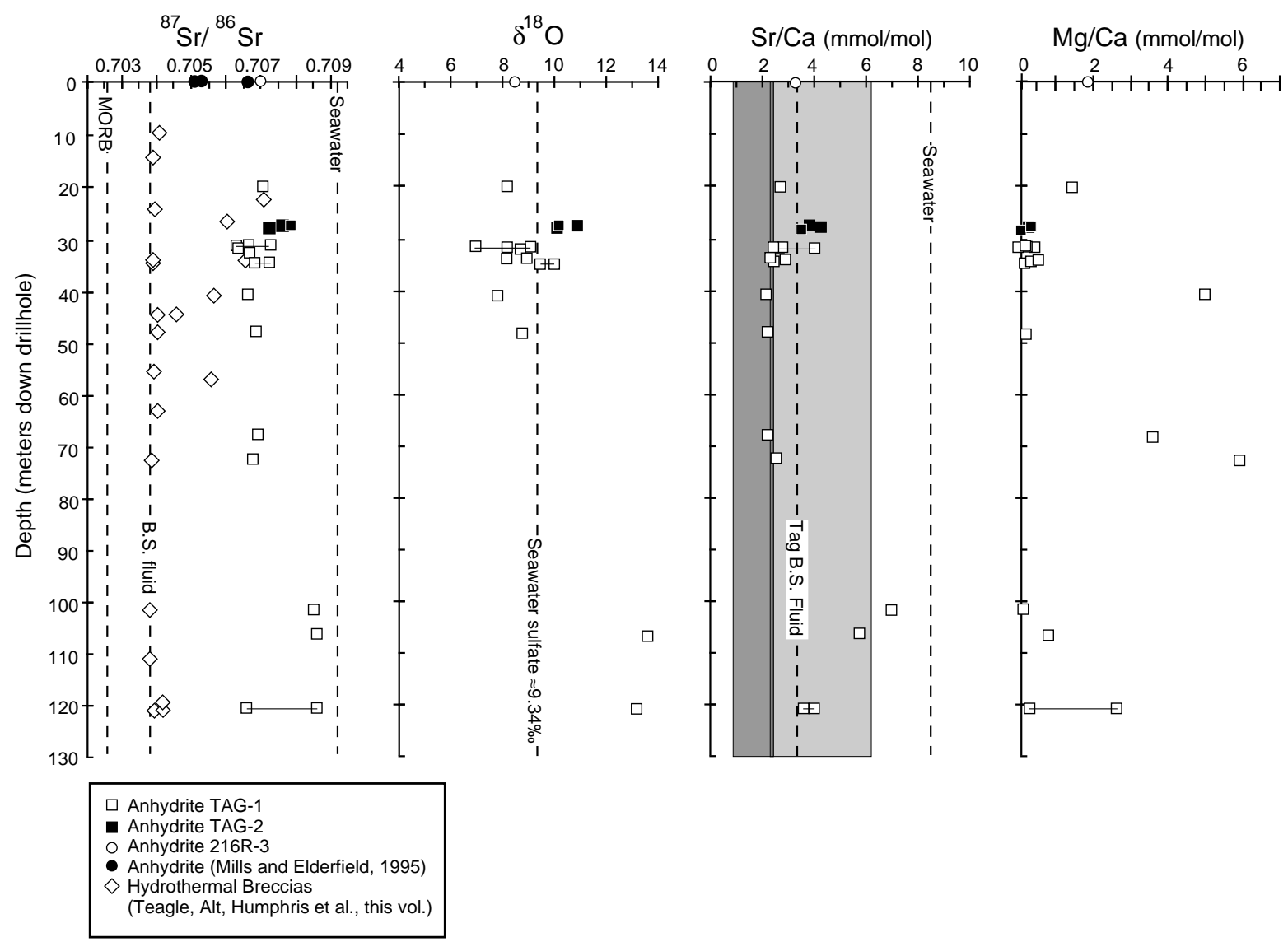

Figure 4. Composite plots for all drill holes showing the variation of ${ }^{87} \mathrm{Sr} /{ }^{86} \mathrm{Sr}, \delta^{18} \mathrm{O}$, and cation ratios $(\mathrm{Sr} / \mathrm{Ca}$ and $\mathrm{Mg} / \mathrm{Ca}$ ) of anhydrite with depth. Tie lines join subsamples from the same piece. ${ }^{87} \mathrm{Sr} /{ }^{86} \mathrm{Sr}$ of hydrothermal assemblages (silicified-pyritized-paragonitized breccias and basaltic clasts) from the TAG mound and stockwork are shown for reference (see Teagle et al., Chap. 22, this volume). Vertical dashed lines show the Sr-isotopic composition of TAG mid-ocean ridge basalt $\left({ }^{87} \mathrm{Sr} /{ }^{86} \mathrm{Sr} \approx 0.7026\right.$; Teagle et al., Chap. 22 , this volume), TAG black smoker fluids ${ }^{87} \mathrm{Sr} /{ }^{86} \mathrm{Sr} \approx 0.7038$; Edmond et al., 1995; Teagle et al., Chap. 22 , this volume), and modern seawater ${ }^{87} \mathrm{Sr} /{ }^{86} \mathrm{Sr} \approx 0.70918$; Hodell et al., 1991). Seawater sulfate oxygen has $\delta^{18} \mathrm{O} \approx 9.34 \%$. Sr/Ca ratios of seawater $(8.53 \mathrm{mmol} /$ $\mathrm{mol}$ ) and TAG black smoker fluid $(3.34 \mathrm{mmol} / \mathrm{mol}$ ) are shown. The ranges of $\mathrm{Sr} / \mathrm{Ca}$ ratios for anhydrite precipitated from the seawater (light shading) and black smoker fluids (dark shading) estimated using experimentally determined partition coefficients are shown (see text for discussion; Shikazono and Holland, 1983; Berndt et al., 1988).

ous trend in this ratio with depth, and whereas the surface sample has a higher $\mathrm{Mg} / \mathrm{Ca}$ than most of the samples, there are others at intermediate depths with higher $\mathrm{Mg}$ contents. $\mathrm{Mg}$ is assumed to be absent from hydrothermal fluids but present in seawater at high concentrations (52.7 mM; Von Damm et al., 1985). Consequently, a positive correlation between strontium-isotopic composition and $\mathrm{Mg} / \mathrm{Ca}$ of anhydrite might be predicted, but no such relationship exists for this data. Elevated $\mathrm{Mg} / \mathrm{Ca}$ values may indicate the presence of minor amounts of either intergranular talc or Mg-hydroxide-sulfate-hydrate. This latter phase can precipitate from seawater-hydrothermal fluid mixtures at high temperatures $\left(>240^{\circ} \mathrm{C}\right.$; Bischoff and Seyfried, 1978) and occurs in sub-microscopic amounts in black smoker chimneys from the East Pacific Rise (Haymon and Kastner, 1986).

\section{DISCUSSION}

Despite the recognition of the important role that anhydrite must play in many aspects of hydrothermal circulation, and the abundance of this mineral in hydrothermal mounds and within black and white smoker chimneys, there is a surprising dearth of comprehensive chemical and isotopic data for this important mineral phase. The combined use of different isotopic systems (e.g., $\delta^{34} \mathrm{~S}, \delta^{18} \mathrm{O}$, and ${ }^{87} \mathrm{Sr} /$ ${ }^{86} \mathrm{Sr}$ ) and appropriate trace-element analyses is a powerful tool in constraining the physical and chemical conditions of anhydrite pre- cipitation and understanding fluid mixing and the possible evolution paths of fluid compositions.

\section{Mixing Between Seawater and Black Smoker Fluids}

Calcium sulfate becomes saturated and anhydrite will precipitate when seawater is heated above $\sim 150^{\circ} \mathrm{C}$ (Bischoff and Seyfried, 1978). The heating of seawater may occur by two principal mechanisms: (1) conductive heating by the wallrock, and (2) mixing with hot hydrothermal fluids. The chemical composition and the isotopic signature of anhydrite will reflect the relative importance of these two processes. As no anhydrite sample yielded a pure seawater ${ }^{87} \mathrm{Sr} /{ }^{86} \mathrm{Sr}$ value, some mixing between seawater and hydrothermal fluids is required for all anhydrite analyzed in this study. As a starting point for the following discussions it is assumed that anhydrite formed in the TAG hydrothermal deposit was precipitated from mixtures of endmember black smoker fluids and seawater. It is also assumed that the chemical and isotopic composition of TAG black smoker fluid has not varied significantly over the lifetime of the deposit (see Teagle et al., Chap. 22, this volume). Measurements of fluid inclusions in both quartz and anhydrite from the TAG mound (Tivey et al., Chap. 14, this volume; Petersen et al., Chap. 13, this volume; Chiba et al., Chap. 6 , this volume) yield a range in salinities, which possibly indicates variable hydrothermal fluid compositions (e.g., Palmer, 1992). Although other scenarios that include multistage mixing of end-member and evolved hydrothermal fluids with seawater probably do occur 
within the TAG deposit, we are unable to distinguish these more complex situations from simple, single-stage mixing between constant end-members, using the chemical and isotopic tools available.

The Sr- and O-isotopic compositions and cation contents of seawater and TAG black smoker fluid are listed in Table 2. Using these values, the strontium-isotopic composition, cation contents $(\mathrm{Ca}, \mathrm{Mg}$, and $\mathrm{Sr}$ ), and sulfate concentrations of mixtures of seawater and endmember black smoker fluids can be calculated (Fig. 5A). A number of simplifications are made in these and other following mixing calculations. A constant specific heat capacity is used, and it is assumed that there has been no conductive heating or cooling of the end-member fluids during mixing. If mixing is rapid, these effects will be minor and may partially offset one another (Janecky and Seyfried, 1984). For simplicity, it is assumed that fluids mix entirely before mineral precipitation, and that the bulk properties of the minerals that precipitate record the chemistry and physical conditions of the homogeneous mixture. When precipitation occurs, it is assumed that anhydrite precipitates until either the reservoir of sulfate or $\mathrm{Ca}(+\mathrm{Sr})$ is exhausted. This "closed" system approach may not be entirely appropriate for an active, highly permeable system such as the TAG hydrothermal deposit, but it provides a useful starting point.

The relative $\mathrm{Ca}$ concentration of TAG hydrothermal fluids compared to seawater is much greater than this ratio for Sr. Hence, there is a significant change in the $\mathrm{Sr} / \mathrm{Ca}$ ratio for different proportions of seawater and hydrothermal fluids (Figs. 4, 5A) with seawater-rich fluids having much higher molar $\mathrm{Sr} / \mathrm{Ca}$ ratios than mixtures dominated by hydrothermal fluids. Assuming that these mixtures are supersaturated in $\mathrm{CaSO}_{4}$ and that all the $\mathrm{CaSO}_{4}$ precipitates as anhydrite, a stoichiometric match between the available sulfate and $\mathrm{Ca}(+\mathrm{Sr})$ occurs only for a mixture containing $\sim 63.5 \%$ seawater (Fig. $5 \mathrm{~A}$ ). This is also the mixture that yields the greatest amount of anhydrite per $\mathrm{kg}$ of fluid if precipitation is complete $(\approx 2.4 \mathrm{~g}$ anhydrite per $\mathrm{kg}$ fluid). Mixtures with less seawater will exhaust the supply of sulfate before $\mathrm{Ca}$ and $\mathrm{Sr}$ are completely removed, resulting in evolved hydrothermal fluids with intermediate strontium-isotopic compositions but altered $\mathrm{Sr} / \mathrm{Ca}$ values and $\mathrm{Sr}$ and $\mathrm{Ca}$ concentrations. Mixtures with greater than $63.5 \%$ seawater have insufficient $\mathrm{Ca}(+\mathrm{Sr})$ to precipitate all the available sulfate, and fluids with highly depleted Ca concentrations may result. Clearly the effects of multiple stages of mixing, precipitation/partial precipitation can become extremely complex. The calculations that follow show that for this data set, complex mixing-precipitation scenarios are not necessary and that the chemical and isotopic data can be adequately explained by simple single-stage mixing of seawater and black smoker fluid end members. With the exception of the three samples with near seawater-like ${ }^{87} \mathrm{Sr} /{ }^{86} \mathrm{Sr}$ ratios, all anhydrite from the TAG mound analyzed in this study appear to have precipitated from mixtures of seawater and black smoker fluids in proportions close to that at which $\mathrm{Ca}(+\mathrm{Sr})$ and $\mathrm{SO}_{4}$ are present in equal concentrations ( $\sim 63 \pm 15 \%$ seawater; Table 1; Fig. 5).

\section{Sr/Ca Partition Coefficient for Anhydrite}

$\mathrm{Sr} / \mathrm{Ca}$ and ${ }^{87} \mathrm{Sr} /{ }^{86} \mathrm{Sr}$ ratios for anhydrite from the TAG hydrothermal mound and stockwork are plotted in Figure 5B. Curves show the predicted $\mathrm{Sr} / \mathrm{Ca}$ ratio for anhydrite precipitated from mixtures of hy-

Table 2. Properties of end-member solutions used in mixing calculations in this manuscript.

\begin{tabular}{lcl}
\hline & Black smoker fluid & Seawater \\
\hline Temperature $\left({ }^{\circ} \mathrm{C}\right)$ & $363^{*}$ & 2 \\
$\mathrm{Mg}(\mathrm{mM})$ & 0 & 52 \\
$\mathrm{Ca}(\mathrm{mM})$ & $30.8^{*}$ & 10.2 \\
$\mathrm{Sr}(\mu \mathrm{M})$ & $103^{*}$ & 87 \\
$\mathrm{SO}(\mathrm{mM})$ & 0 & 27.9 \\
$\delta^{18} \mathrm{O}(\%)$ & $1.7 \S$ & 0 \\
${ }^{87} \mathrm{Sr} /{ }^{86} \mathrm{Sr}$ & $0.7038^{*}$ & $0.70918^{\dagger}$ \\
\hline
\end{tabular}

Note: * = Edmond et al. (1995); $\dagger=$ Hodell et al. (1991); $\S=$ Shanks et al. (119); other data from Von Damm (1995), and references therein. drothermal fluid and seawater for different arbitrary $\mathrm{Sr} / \mathrm{Ca}$ partition coefficients calculated using:

$$
\mathrm{K}_{d}^{\mathrm{Sr}}=\left(a_{\mathrm{SrSO}_{4}} / a_{\mathrm{CaSO}_{4}}\right) /\left(a_{\left.\mathrm{Sr}^{2+} / a_{\mathrm{Ca}^{2+}}\right)}\right.
$$

where is the partition or distribution coefficient for $\mathrm{Sr}$, and $a_{x}$ is the activity of the respective phases or ions (after Shikazono and Holland, 1983). For the purposes of this study, measured or calculated concentrations have been employed rather than undertaking sophisticated estimations of activity. Most anhydrites plot within the enve-
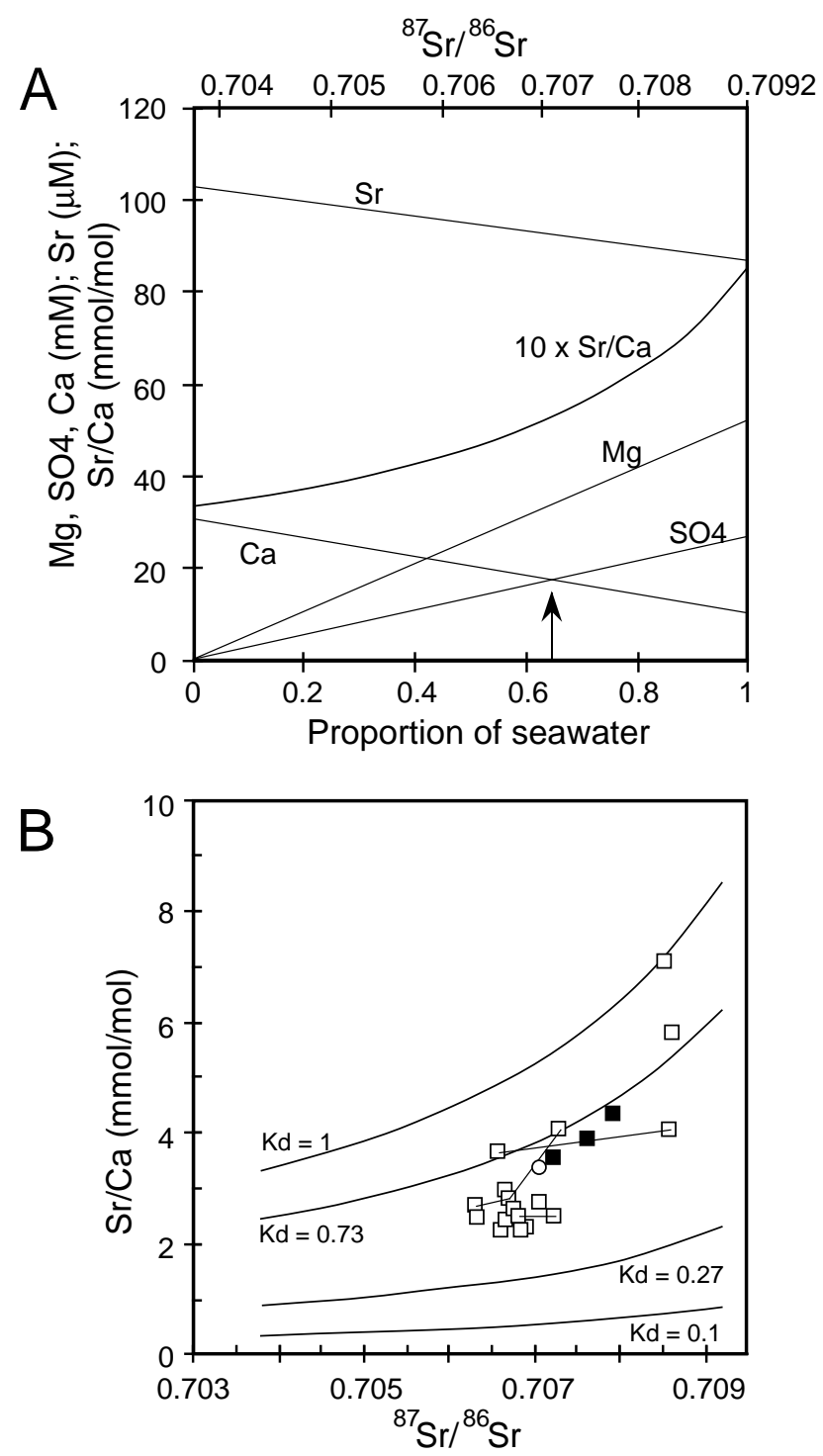

Figure 5. A. Cation and sulfate concentrations of mixtures between endmember black smoker fluids and seawater assuming no mineral precipitation. Note that for mixtures with less than $\sim 63 \%$ seawater there is insufficient $\mathrm{SO}_{4}{ }^{2-}$ in the mixture to completely remove $\mathrm{Ca}$ (and $\mathrm{Sr}$ ) from the solution by anhydrite precipitation. Mixtures richer in hydrothermal fluids will tend to become more $\mathrm{Ca}$ rich and complex mixtures can develop by multistage mixing between end-member fluids and multiple precipitation events. Note that because of the slightly different concentrations of $\mathrm{Sr}$ in seawater and hydrothermal fluids (Table 2), the upper scale for ${ }^{87} \mathrm{Sr} /{ }^{86} \mathrm{Sr}$ is not linear. B. Measured ${ }^{87} \mathrm{Sr} /{ }^{86} \mathrm{Sr}$ vs. measured $\mathrm{Sr} / \mathrm{Ca}$ of anhydrite from the TAG mound and stockwork. Symbols as in Figure 4. Tielines link neighboring subsamples. Calculated curves show the range of predicted anhydrite compositions precipitated from mixtures of hydrothermal fluid and seawater for an arbitrary range of $\mathrm{Sr} / \mathrm{Ca}$ partition coefficients. 
lope defined by the lines that delineate the expected $\mathrm{Sr} / \mathrm{Ca}$ ratios of anhydrite predicted for $K_{d}=0.27$ to 0.73 , as recommended by Shikazono and Holland (1983) and Berndt et al. (1988). Two samples with high ${ }^{87} \mathrm{Sr} /{ }^{86} \mathrm{Sr}$ ratios suggest higher partition coefficients, though still $<1$ if they precipitated from simple mixtures of seawater and hydrothermal fluid. There is adequate agreement between this data and experimental determinations of partition coefficient.

A detailed analysis of $\mathrm{Sr} / \mathrm{Ca}$ partition coefficients for anhydrite is beyond the scope of this manuscript, and in particular comparison with laboratory calibrations is difficult, because the geologist and the experimentalist commonly measure different parameters. For example, Shikazono and Holland (1983) calculate partition coefficients for constant volume experiments from the final concentrations of $\mathrm{Sr}$ and $\mathrm{Ca}$ in the fluid and the bulk $\mathrm{Sr}$ and Ca contents of precipitated anhydrite. Although the latter parameter can be measured, in natural systems the composition of the fluid after anhydrite precipitation is difficult to estimate directly, though the composition of the initial fluid can be calculated from the ${ }^{87} \mathrm{Sr} /{ }^{86} \mathrm{Sr}$ ratio of the anhydrite assuming mixing of defined end-members. The experiments of Shikazono and Holland (1983) do suggest, however, that the partition coefficient for anhydrite depends less on temperature or chlorinity and more on the degree of anhydrite supersaturation of the solution before precipitation, and on the morphology of the anhydrite that crystallizes.

There is only limited chemical and isotopic data for anhydrite from either ancient ore deposits or active hydrothermal systems available for comparison with the new TAG analyses presented here. Although there is abundant trace-element and strontium- and oxygen-isotopic data for anhydrite from the Kuroko deposits of Japan (Watanabe and Sakai, 1983; Kusakabe and Chiba, 1983; Farrell and Holland, 1983; and Shikazono et al., 1983), the hydrothermal fluids responsible for the formation of these deposits are only poorly constrained, and, hence, worthwhile comparisons with the TAG anhydrite cannot be made. There is limited $\mathrm{Sr}$ data available for anhydrite from the $21^{\circ} \mathrm{N}$ hydrothermal vent field on the East Pacific Rise, where the composition and temperature of vent fluids are known (Von Damm et al., 1985). Values of ${ }^{87} \mathrm{Sr} /{ }^{86} \mathrm{Sr}$ have been measured for a number of samples (Albarède et al., 1981) collected from this field, but $\mathrm{Sr}$ concentrations are reported for only one sample (Vidal and Clauer, 1981). Strontium contents of six anhydrites from the $21^{\circ} \mathrm{N}$ East Pacific Rise vent sites range from $1950 \mathrm{ppm}$ to $3520 \mathrm{ppm}$ (Shikazono and Holland, 1983; c.f. 1400 ppm-4500 ppm for TAG samples, Table 1). Partition coefficients have been calculated for the East Pacific Rise $21^{\circ} \mathrm{N}$ anhydrite using all possible combinations of vent fluid chemistry and anhydrite strontium contents and ${ }^{87} \mathrm{Sr} /{ }^{86} \mathrm{Sr}$ ratios, assuming mixing with seawater and hydrothermal fluids, and applying Equation 1 above. A histogram of partition coefficients for the TAG samples is plotted in Figure 6 and an average $K_{d}$ of $0.60 \pm$ $0.28(2 \sigma)$ is estimated. Also shown on this diagram is the range of recommended $K_{d}$ from experimental data and the range of calculated $K_{d}$ estimated for anhydrite from the $21^{\circ} \mathrm{N}$ vent field. The single analysis of Vidal and Clauer (1981) is shown separately. There is good overlap between these different studies and the $K_{d}$ estimates from samples from the TAG mound are near the middle of the other ranges. A $K_{d}$ of 0.6 will be used for other calculations later in this manuscript.

\section{Oxygen-Isotopic Controls on Fluid-Mixing and Conditions of Anhydrite Precipitation}

The oxygen-isotopic composition of minerals can provide an estimate of the temperature of precipitation of that mineral if the composition of the parent fluid is known and the temperature dependent isotopic fractionation curve is defined. An oxygen-isotope fractionation factor between anhydrite and water has been determined by Chiba et al. (1981) for temperatures between $100^{\circ} \mathrm{C}$ and $550^{\circ} \mathrm{C}$ :

$$
10^{3} \ln \alpha_{\text {anhydrite-water }}=3.21 \times\left(10^{3} / \mathrm{T}\right)^{2}-4.72
$$

and this geothermometer has been successfully applied to anhydrite from some natural hydrothermal systems.

The temperatures of precipitation for anhydrite from the TAG mound and stockwork can be estimated for mixtures of $363^{\circ} \mathrm{C}$ hydrothermal fluids and $2^{\circ} \mathrm{C}$ seawater using the ${ }^{87} \mathrm{Sr} /{ }^{86} \mathrm{Sr}$ of the anhydrite (Table 1). These apparent temperatures range from $34^{\circ}$ to $177^{\circ} \mathrm{C}$, with many samples yielding temperatures well below $130^{\circ} \mathrm{C}$, conditions where anhydrite would not be expected to precipitate (Bischoff and Seyfried, 1978). Clearly, conductive heating of seawater is required in order to account for the abundance of anhydrite in the mound and underlying stockwork.

Temperatures calculated from the $\delta^{18} \mathrm{O}$ of anhydrite using Equation 2 and assuming oxygen isotopic equilibrium with, and precipitation from, heated seawater $(0 \%)$ are in the range $146^{\circ} \mathrm{C}$ to $250^{\circ} \mathrm{C}$ (Table 1). Temperatures are also calculated assuming that anhydrite precipitated in isotopic equilibrium with mixtures of seawater $(0 \%$ ) and hydrothermal fluid (1.7\%o; Shanks et al., 1995), using the mixing proportions indicated by the anhydrite ${ }^{87} \mathrm{Sr} /{ }^{86} \mathrm{Sr}$ ratios. Estimated temperatures are in the range $147^{\circ}-270^{\circ} \mathrm{C}$ (Table 1), consistent with the precipitation temperature established experimentally by Bischoff and Seyfried (1978), as well as the high degree of supersaturation required before precipitation will occur (e.g., Shikazono and Holland, 1983; Prieto et al., 1990; Putnis et al., 1995).

Measured strontium- and oxygen-isotopic compositions are plotted on Figure 7A, along with trajectories that delineate the expected oxygen-isotopic composition of anhydrite precipitated from mixtures of seawater and hydrothermal fluids. Trajectories for different initial temperatures of seawater are shown. The mixing calculations take into account both the oxygen-isotopic composition of the mixture as well as the temperature of the mixture before the resulting composition of the anhydrite is computed. It is assumed that seawater can be conductively heated before mixing with black smoker fluids $(\mathrm{T} \approx$ $363^{\circ} \mathrm{C}$ ). No data points fall on the mixing line between ambient ocean bottom water $\left(\mathrm{T} \approx 2^{\circ} \mathrm{C}\right)$ and black smoker fluids. The $\mathrm{Sr}$ - and $\mathrm{O}$-isotopic composition of anhydrite precipitated within the TAG mound and stockwork can be most simply explained by precipitation from mixtures of end-member black smoker fluids with seawater that has been conductively heated to between $100^{\circ}$ and $180^{\circ} \mathrm{C}$ before mixing. The conductive heating of seawater is consistent with oxygen isotopic data for quartz, which indicates convective cooling of the TAG mound (Alt and Teagle, Chap. 21, this volume). Two samples with

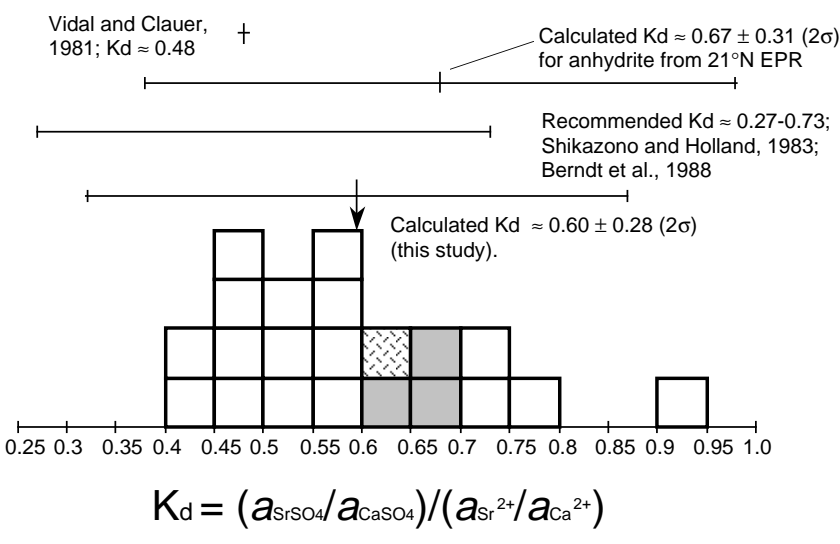

Figure 6. Histogram showing the range in $\mathrm{Sr} / \mathrm{Ca}$ partition coefficient for anhydrite calculated for TAG samples assuming mixing between black smoker fluids and seawater. Hatched box = surface sample 216R-3; gray boxes $=$ TAG- 2 anhydrite; white boxes $=$ TAG- 1 anhydrite. The range of partition coefficients calculated for anhydrite from $21^{\circ} \mathrm{N}$ East Pacific Rise using data from Von Damm et al., 1985; Albarède et al., 1981; Shikazono and Holland, 1983; and Vidal and Clauer, 1981, is shown for comparison. 
elevated Sr- and O-isotopic compositions from near the bottom of the TAG-1 drill cores also fall along these mixing trajectories. Neighboring subsamples fall along the same trajectory for different amounts of conductive heating, and the data as a whole approximately parallel the mixing envelope. Possible conductive cooling of hydrothermal fluids before mixing is not considered on this diagram, but the curves would bracket the observed data, albeit at gentler gradients.

Figure $7 \mathrm{~B}$ plots the apparent temperature estimated from the ${ }^{87} \mathrm{Sr} /$ ${ }^{86} \mathrm{Sr}$ of anhydrite and mixtures of ambient seawater and black smoker fluids vs. the temperature estimated from the measured $\delta^{18} \mathrm{O}$ of anhydrite precipitated from a mixture of fluids. No samples fall along the $1: 1$ gradient of mixing between $2^{\circ} \mathrm{C}$ ocean bottom water and $363^{\circ} \mathrm{C}$ hydrothermal fluid. The temperature to which seawater must be conductively heated before mixing can be estimated by projecting a line
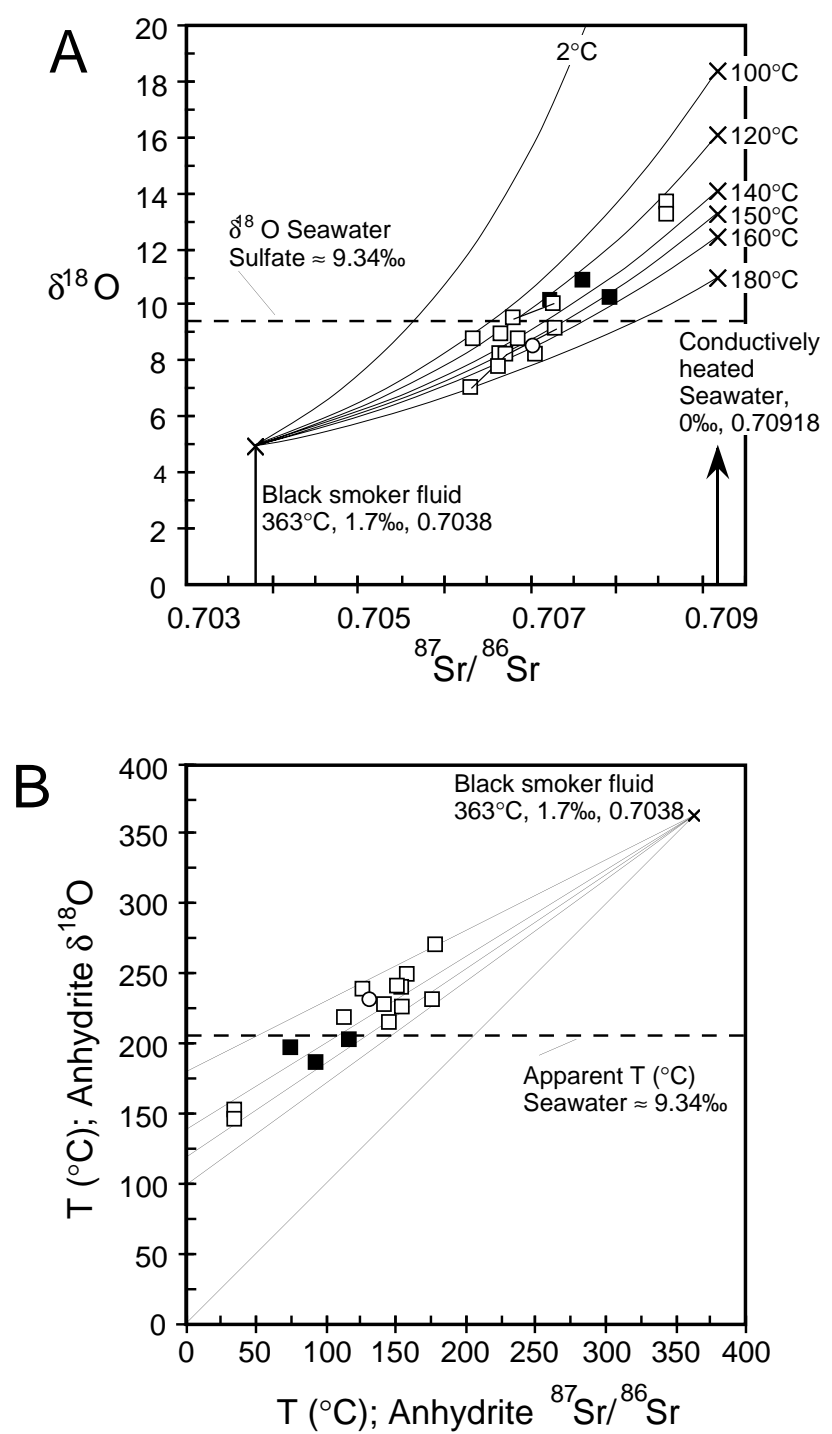

Figure 7. A. ${ }^{87} \mathrm{Sr} /{ }^{86} \mathrm{Sr}$ vs. $\delta^{18} \mathrm{O}$ for anhydrite from the TAG hydrothermal mound. Trajectories are calculated for the Sr- and oxygen-isotopic composition of anhydrite precipitated from mixtures of hydrothermal fluid with seawater that has been conductively heated to the labeled temperatures before mixing. B. Estimates of the temperature of anhydrite precipitation calculated from the ${ }^{87} \mathrm{Sr} /{ }^{86} \mathrm{Sr}$ assuming mixing between ambient ocean bottom water and black smoker fluids, and temperature determined from $\delta^{18} \mathrm{O}$ using the fractionation calibration of Chiba et al. (1981). from the black smoker composition through a point of interest to the vertical temperature axis.

Compositional and thermal effects on the anhydrite $\mathrm{Sr} / \mathrm{Ca}$ partition coefficient are investigated in Figure 8. Partition coefficients calculated from Equation 1 are plotted vs. the measured ${ }^{87} \mathrm{Sr} /{ }^{86} \mathrm{Sr}$ value of anhydrite. There is not a strong correlation between these parameters, though some of the most seawater-rich samples do have the highest calculated partition coefficients. An apparent trend of decreasing $K_{d}$ with increasing temperature is suggested when the calculated $K_{d}$ is compared with temperature estimated from the oxygenisotopic composition, but this correlation is not statistically valid. Partition coefficients determined experimentally (Shikazono and Holland, 1983) do not show a consistent trend with temperature of precipitation.

\section{Buffering of the Oxygen-Isotopic Composition of Oceanic Sulfate by Hydrothermal Circulation}

Sulfate oxygen-isotopic exchange between fluids and anhydrite is strongly inhibited in the laboratory experiments (Chiba et al., 1981; Chiba and Sakai, 1985) suggesting that kinetic effects can be important in natural systems, particularly at low temperature and in neutral or alkaline solutions. The sluggishness of sulfate-oxygen isotopic exchange is highlighted by the isotopic composition of seawater sulfate $\left(\delta^{18} \mathrm{O} \approx 9.34 \%\right.$ o), which is much lower than the equilibrium value calculated for $4^{\circ} \mathrm{C}$ seawater of $+38 \%$ (Lloyd, 1967, 1968). The calibration of Chiba et al. (1981) suggests that oceanic sulfate oxygen is in equilibrium with seawater at approximately $200^{\circ} \mathrm{C}$.

The reason for the isotopic disequilibrium between seawater and sulfate oxygen is not established. Haymon and Kastner (1986) suggested that the precipitation of anhydrite and "caminite" (Mg hydroxide sulfate hydrate) at $130^{\circ}$ and $240^{\circ} \mathrm{C}$, respectively, in the ocean crust during hydrothermal recharge and then the dissolution of these minerals at lower temperatures when the crust cools off-axis, could provide the reservoir of isotopically light sulfate oxygen needed to maintain ocean waters in the apparent isotopic disequilibrium. No oxygen-isotopic data was presented to support their hypothesis but recent analyses of $\delta^{18} \mathrm{O}$ of anhydrite precipitated in the sheeted dike complex of Hole 504B during hydrothermal recharge do indicate precipitation from evolved seawater-derived fluids at elevated temperatures that approach $200^{\circ} \mathrm{C}$ (Teagle et al., 1995).

The abundance of anhydrite in the TAG mound and its ${ }^{87} \mathrm{Sr} /{ }^{86} \mathrm{Sr}$ ratio indicate that very large volumes of ocean bottom water are entrained into the mound and that anhydrite precipitates because seawater mixes with hydrothermal fluids. Thermal budget constraints require that vigorous hydrothermal venting cannot be continuous, and high-temperature fluid egress probably occurs for less than $25 \%$ of the time (e.g., Sleep, 1991). Episodic activity at the TAG site has been indicated from U-Th systematics of hydrothermal minerals (Lalou et al, 1993, 1995, Chap. 9, this volume). The absence of anhydrite, presence of hydrothermal assemblages, and very low conductive heat flow (Becker and Von Herzen, 1996) in the TAG-4 area requires that the thermal structure of the mound and stockwork can change and that significant cooling may occur both because of variations in the shallow-level fluid pathways, as well as fluctuations in the supply of magma at depth that drives the large-scale hydrothermal circulation.

The absence of anhydrite from ancient deposits found in ophiolites and the extinct Alvin and Mir mounds in the near vicinity of the TAG mound (Rona et al., 1993), and the corrosion of anhydrite that crops out atop the active TAG deposit, indicate that anhydrite does dissolve with cooling and sulfate is returned to the ocean. Strontiumand oxygen-isotopic data presented here suggest that anhydrite formed at elevated temperatures in equilibrium with mixtures of black smoker fluids and conductively heated seawater, and the $\delta^{18} \mathrm{O}$ of the anhydrite brackets the composition of sulfate oxygen in seawater. The strong kinetic inhibition of oxygen isotopic exchange at low temperatures means that anhydrite that attained oxygen-isotopic 

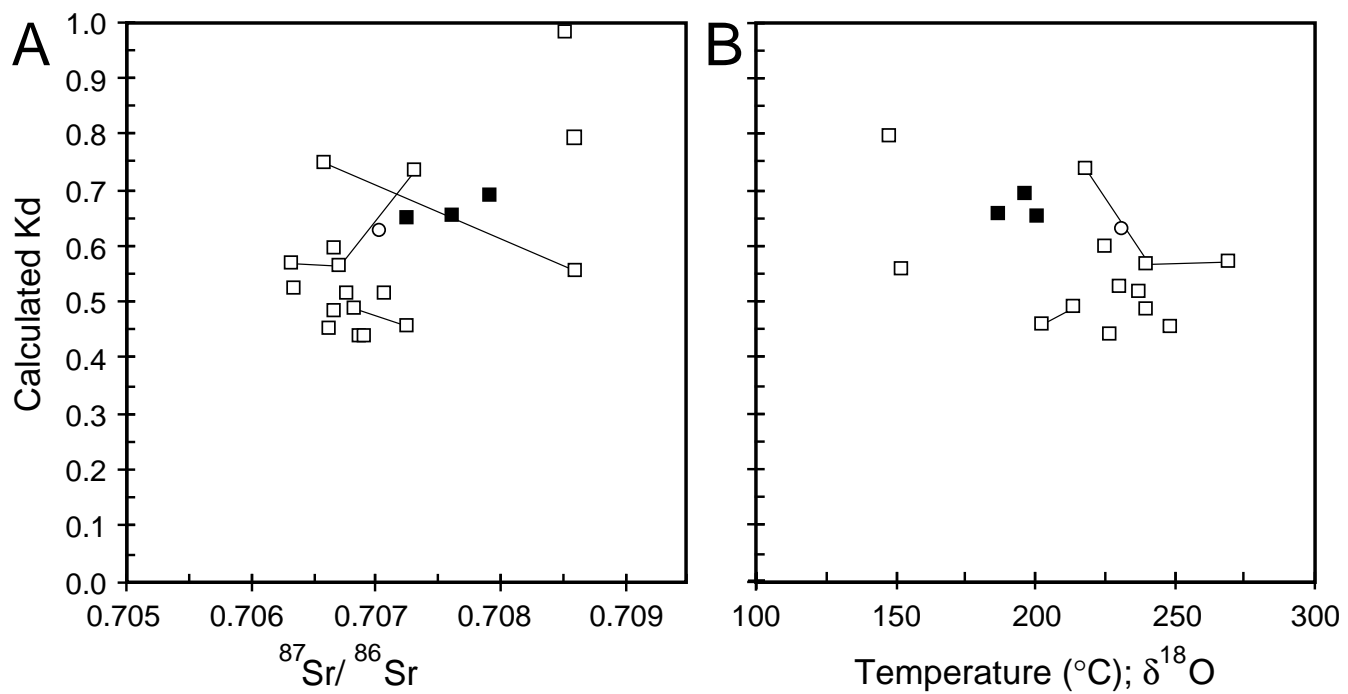

Figure 8. Partition coefficients for anhydrite from the TAG mound calculated plotted vs. (A) ${ }^{87} \mathrm{Sr} /{ }^{86} \mathrm{Sr}$ and (B) temperature of precipitation estimated from $\delta^{18} \mathrm{O}$.

equilibrium with fluids at elevated temperature will release sulfate on dissolution, and that this sulfate retains a high-temperature oxygenisotopic signature. The precipitation of anhydrite within large hydrothermal mounds such as the TAG deposit, or even larger systems found in arc environments (e.g., Kuroko) may act as a major source of isotopically light sulfate oxygen into the oceanic during periods of hydrothermal quiescence at these sites, when low temperatures cause the anhydrite to redissolve. Hence, mixing between seawater and black smoker fluids in hydrothermal deposits provides an additional mechanism for the continuous buffering of oceanic sulfate to light oxygen isotopic values, and it complements the dissolution off-axis of anhydrite (and "caminite") precipitated near-axis during largescale hydrothermal recharge (Haymon and Kastner, 1986; Teagle et al., 1995).

\section{Precipitation of Anhydrite During Drilling?}

Three anhydrite samples measured in this study have highly elevated Sr-isotopic compositions, which suggest precipitation from seawater only slightly diluted by hydrothermal fluid ( $\mathrm{X}^{\text {seawater }}>90 \%$; Table 1). These samples are all from the bottom of the Hole 957E in the TAG-1 drilling area at depths greater than $100 \mathrm{~m}$ below the surface of the mound. The oxygen-isotopic composition of these samples is 3\%o-4\%o higher than the average anhydrite. Mills et al. (Chap. 10 , this volume) report a trend of increasing ${ }^{87} \mathrm{Sr} /{ }^{86} \mathrm{Sr}$ in anhydrite with depth, though the data coverage with depth in both that and this study is insufficient to evaluate the robustness of this trend. A single analysis of anhydrite from the very bottom of Hole 957E (Sample 158-957E-18R-1, 20-24 cm), from a vein that forms the bulk of the anhydrite in this specimen and records an early phase of anhydrite precipitation, yields a ${ }^{87} \mathrm{Sr} /{ }^{86} \mathrm{Sr}$ ratio $(\approx 0.7066)$ similar to the bulk of the samples encountered higher in the mound and stockwork. It is late-stage, delicate, clear, tabular anhydrite that has grown into an open space in this specimen that has a seawater-like ${ }^{87} \mathrm{Sr} /{ }^{86} \mathrm{Sr}$ ratio (0.7086; see Table 1). It should be noted however, that other anhydrite samples from deep in the TAG stockwork that yield high ${ }^{87} \mathrm{Sr} /$ ${ }^{86} \mathrm{Sr}$ ratios (e.g., Samples 158-957E- 14R-1 [Piece 10] and 15R-1 [Piece 4]; Table 1) do not have a delicate morphology and are not unambiguously of a relatively late-stage origin.

The strontium- and oxygen-isotopic compositions of these anomalous anhydrites can be explained by precipitation from a 10:90 mix of black smoker fluid with seawater that has been conductively heated to $120^{\circ}$ to $130^{\circ} \mathrm{C}$. The high proportion of seawater in this mixture so deep beneath the mound requires either huge seawater fluxes and/ or the presence of a highly permeable conduit. This channel would have to enable ocean water to penetrate to deep levels in the stockwork, without reacting with wallrocks comprising either hydrothermal assemblages $\left({ }^{87} \mathrm{Sr} /{ }^{86} \mathrm{Sr} \approx 0.7038\right)$ and altered basalts $\left({ }^{87} \mathrm{Sr} /{ }^{86} \mathrm{Sr} \approx\right.$ 0.7026 to 0.7032 ; Teagle et al., Chap. 22, this volume), and without mixing with hydrothermal fluids until the fluid reached the very deepest levels of the drilled section. The presence of such a natural seawater channel cannot be discounted, and certainly low-temperature fluids within the cold basaltic basement that surrounds the mound are probably only slightly evolved from seawater, by analogy to other basement sites (e.g., Site 896; Teagle et al., 1996). However, one explanation of the textural and isotopic evidence is that seawater penetrated into the subsurface down the drill string during coring, and that some of the anhydrite recovered precipitated during the drilling operations.

When drilling, seawater is rapidly circulated through the bottom hole assembly to clear cuttings and cool the bit, and this should inhibit anhydrite precipitation. It is however, possible that seawater may percolate into the stockwork zone ahead of the drill bit to outside the zone of cooling and on heating and mixing with hydrothermal fluids precipitate anhydrite. Severe drilling problems were encountered during the return to Hole 957E (Humphris, Herzig, Miller, et al., 1996). After the retrieval of Core 158-957E-13R (96.8-101.5 mbsf), the drill pipe became stuck and extensive pumping and reaming occurred before rotation was reestablished and coring operations could continue. Samples of anhydrite with near seawater-like strontiumisotopic compositions all come from cores deeper than Core 158957E-13R (Cores 158-957E-14R to 18R, 101.5-125.7 mbsf).

\section{CONCLUSIONS}

The abundance of anhydrite recovered from the TAG mound and the underlying mineralized stockwork zone attests to the large volume of ocean bottom water that must be entrained into the mound. This ingress of seawater and precipitation of anhydrite is an important factor affecting the evolving thermal and permeability structure of the TAG mound, and anhydrite must play a significant role in mound construction and mass wasting during episodes of hydrothermal activity and quiescence respectively.

Cupriferous ore deposits found in ophiolites are believed to be fossil analogs of mounds presently active at the ridge crests, but the role of anhydrite in their formation has generally not been considered. Anhydrite is not preserved in these deposits as it will dissolve in seawater at low temperature $\left(<100^{\circ} \mathrm{C}\right)$. The textures of sulfide ores preserved within ophiolite deposits need to be reappraised to see 
whether the effects of the dissolution of an early anhydrite cement from disseminated pyrite and chalcopyrite can be recognized.

Strontium-isotopic compositions indicate that anhydrite within the TAG mound precipitated from near equal proportion mixtures of seawater and end-member black smoker fluids $(\approx 63 \pm 15 \%$ seawater). Samples from throughout the mound broadly have similar Srand $\mathrm{O}$-isotopic and cation compositions, but chemistries are heterogeneous at a centimeter scale, with neighboring samples showing nearly the full range in chemical parameters. This reflects the dynamic thermal conditions and changing mixing regimes within the active mound and stockwork. Three anhydrite samples from deep in the mound have near-seawater like ${ }^{87} \mathrm{Sr} /{ }^{86} \mathrm{Sr}$ ratios, indicating the penetration of unaltered seawater to deep in the TAG complex. Textural evidence suggests that some of this seawater-like anhydrite is of a very late-stage origin, and some precipitation of anhydrite may have occurred within the mound during drilling operations.

$\mathrm{Sr} / \mathrm{Ca}$ ratios are in agreement with cation compositions from experimentally determined partition coefficients. The TAG anhydrite has an average partition coefficient of $K_{d} \approx 0.60 \pm 0.28(2 \sigma)$, which is similar to coefficients calculated in this study for anhydrite from hydrothermal chimneys at $21^{\circ} \mathrm{N}$ on the East Pacific Rise. There is no statistically valid correlation between the calculated partition coefficient and either ${ }^{87} \mathrm{Sr} /{ }^{86} \mathrm{Sr}$ or $\delta^{18} \mathrm{O}$.

Temperatures of precipitation of anhydrite calculated from mixing between ocean bottom water $\left(2^{\circ} \mathrm{C}\right)$ and black smoker fluids $\left(363^{\circ} \mathrm{C}\right)$ are generally low $\left(<150^{\circ} \mathrm{C}\right)$, below the temperature at which anhydrite would be expected to precipitate. This indicates that significant conductive heating of seawater must have occurred before mixing with black smoker fluids and the precipitation of anhydrite. Temperatures calculated from $\delta^{18} \mathrm{O}$ using established fractionation calibrations (Chiba et al., 1981) are in the range $\left(147^{\circ}\right.$ to $\left.270^{\circ} \mathrm{C}\right)$ indicating that a high degree of supersaturation was required before precipitation occurred. Calculated mixing trajectories indicate that seawater must have been conductively heated to between $100^{\circ}$ and $180^{\circ} \mathrm{C}$ before mixing with end-member black smoker fluids. Conductive heating of seawater is consistent with oxygen-isotopic data for quartz (Alt and Teagle, Chap. 21, this volume), which indicates conductive cooling of the TAG mound.

The $\delta^{18} \mathrm{O}$ of anhydrite brackets the oxygen isotopic composition of seawater sulfate, that is far from equilibrium with ocean water, because of the sluggish kinetics of sulfate oxygen exchange at low temperatures. The precipitation of large volumes of anhydrite in hydrothermal structures such as the TAG mound resulting from the mixing of seawater and hydrothermal fluids provides a significant reservoir of isotopically light sulfate that will return to the oceans on dissolution during episodes of hydrothermal inactivity. This provides an additional source of sulfate with the appropriate oxygen isotopic composition to anhydrite that precipitates within the oceanic basement during hydrothermal recharge at the ridge axis (e.g., Haymon and Kastner, 1986; Teagle et al., 1995).

\section{ACKNOWLEDGMENTS}

The authors gratefully acknowledge Jim R. O'Neil for the use of his laboratory (oxygen isotopes), and John N. Christensen for invaluable technical assistance. The authors would like to thank Hank Jones (sulfate $\delta^{18} \mathrm{O}$ ) and Ted Huston (ICP-AES) for anhydrite analyses. Rachel Mills and Meg Tivey provided some of the anhydrite samples. Reviews by Mike Bickle, Martin Palmer, Richard Carlson, and Laura Stokking helped clarify some of the interpretations presented here. This work was supported by grants from JOI-USSAC to DAHT and JCA, and a grant-in-aid for Scientific Research (No. 06044051) from the Ministry of Education, Science, Sports and Culture, Japan to HC.

\section{REFERENCES}

Albarède, F., Michard, A., Minster, J.F., and Michard, G., 1981. ${ }^{87} \mathrm{Sr} /{ }^{86} \mathrm{Sr}$ ratios in hydrothermal water and deposits from the East Pacific Rise at $21^{\circ}$ N. Earth Planet. Sci. Lett., 55:229-236.

Alt, J.C., 1995. Subseafloor processes in mid-ocean ridge hydrothermal systems. In Humphris, S.E., Zierenberg, R., Mullineaux, L., and Thomson, R. (Eds.), Seafloor Hydrothermal Systems: Physical, Chemical, Biological and Geological Interactions within Hydrothermal Systems. Geophys. Monogr., Am. Geophys. Union, 91:85-114.

Alt, J.C., Anderson, T.F., and Bonnell, L., 1989. The geochemistry of sulfur in a $1.3 \mathrm{~km}$ section of hydrothermally altered oceanic crust, DSDP Hole 504B. Geochim. Cosmochim. Acta, 53:1011-1023.

Becker, K., and Von Herzen, R.P., 1996. Pre-drilling observations of conductive heat flow at the TAG active mound using Alvin. In Humphris, S.E., Herzig, P.M., Miller, D.J., et al., Proc. ODP, Init. Repts., 158: College Station, TX (Ocean Drilling Program), 23-29.

Berndt, M.E., Seyfried, W.E., and Beck, J.W., 1988. Hydrothermal alteration processes at mid-ocean ridges: experimental and theoretical constraints from $\mathrm{Ca}$ and $\mathrm{Sr}$ exchange reactions and $\mathrm{Sr}$ isotopic ratios. J. Geophys. Res., 93:4573-4583.

Bischoff, J.L., and Seyfried, W.E., 1978. Hydrothermal chemistry of seawater from $25^{\circ} \mathrm{C}$ to $350^{\circ} \mathrm{C}$. Am. J. Sci., $278: 838-860$.

Campbell, A.C., Palmer, M.R., Klinkhammer, G.P., Bowers, T.S., Edmond, J.M., Lawrence, J.R., Casey, J.F., Thompson, G., Humphris, S., Rona, P.A., and Karson, J.A., 1988. Chemistry of hot springs on the Mid-Atlantic Ridge. Nature, 335:514-519.

Carpenter, S.J., Lohmann, K.C., Holden, P., Walter, L.M., Huston, T.J., and Halliday, A.N., 1991. $\delta^{18} \mathrm{O}$ values, ${ }^{87} \mathrm{Sr} /{ }^{86} \mathrm{Sr}$ and $\mathrm{Sr} / \mathrm{Mg}$ ratios of Late Devonian abiotic marine calcite: implications for the composition of ancient seawater. Geochim. Cosmochim. Acta, 55:1991-2010.

Chiba, H., Kusakabe, M., Matsuo, S., Hirano, S., and Somiya, S., 1981. Oxygen isotope fractionation factors between anhydrite and water from 100 to $550^{\circ}$ C. Earth Planet. Sci. Lett., 53:55-62.

Chiba, H., and Sakai, H., 1985. Oxygen isotope exchange rate between dissolved sulfate and water at hydrothermal temperatures. Geochim. Cosmochim. Acta, 49:993-1000.

Craig, H., 1961. Standard for reporting concentrations of deuterium and oxygen-18 in natural waters. Science, 133:1833-1834.

Edmond, J.M., Campbell, A.C., Palmer, M.R., German, C.R., Klinkhammer, G.P., Edmonds, H.N., Elderfield, H., Thompson, G., and Rona, P., 1995. Time-series studies of vent fluids from the TAG and MARK sites (1986, 1990): Mid-Atlantic Ridge: a new solution chemistry model and a mechanism for $\mathrm{Cu} / \mathrm{Zn}$ zonation in massive sulfide ore bodies. In Parson, L.M., Walker, C.L., and Dixon, D.R. (Eds.), Hydrothermal Vents and Processes. Geol. Soc. Spec. Publ. London, 87:77-86.

Edmond, J.M., Measures, C., Magnum, B., Grant, B., Sclater, F.R., Collier, R., Hudson, A., Gordon, L.I., and Corliss, J.B., 1979. On the formation of metal-rich deposits at ridge crests. Earth. Planet. Sci. Lett., 46:19-30.

Elderfield, H., Mills, R. A., and Rudnicki, M. D., 1993. Geochemical and thermal fluxes, high-temperature venting and diffuse flow from midocean ridge systems: the TAG hydrothermal field, Mid-Atlantic Ridge $26^{\circ}$ N. In Prichard, H.M., Alabaster, T., Harris, N.B.W., and Neary, C.R. (Eds.), Magmatic Processes and Plate Tectonics Geol. Soc. Spec. Publ. London, 76:295-307.

Farrell, C.W., and Holland, H.D., 1983. Strontium isotope geochemistry of the Kuroko deposits. In Ohmoto, H., and Skinner, B.J. (Eds.), The Kuroko and Related Volcanogenic Massive Sulfide Deposits. Econ. Geol. Monogr., 5:302-319.

Haymon, R.M., 1983. Growth history of hydrothermal black smoker chimneys. Nature, 301:695-698.

Haymon, R.M., and Kastner, M., 1981. Hot spring deposits on the East Pacific Rise at $21^{\circ} \mathrm{N}$ : preliminary description of mineralogy and genesis. Earth Planet. Sci. Lett., 53:363-381.

1986. Caminite: a new magnesium-hydroxide-sulfate-hydrate mineral found in a submarine hydrothermal deposit, East Pacific Rise, $21^{\circ}$ N. Am. Mineral., 71:819-825.

Hodell, D.A., Mueller, P.A., and Garrido, J.R., 1991. Variations in the strontium isotopic composition of seawater during the Neogene. Geology, 19:24-27.

Humphris, S.E., Herzig, P.M., Miller, D.J., Alt, J.C., Becker, K., Brown, D., Brügmann, G., Chiba, H., Fouquet, Y., Gemmell, J.B., Guerin, G., Han- 
nington, M.D., Holm, N.G., Honnorez, J.J., Itturino, G.J., Knott, R., Ludwig, R., Nakamura, K., Petersen, S., Reysenbach, A.-L., Rona, P.A., Smith, S., Sturz, A.A., Tivey, M.K., and Zhao, X., 1995. The internal structure of an active sea-floor massive sulphide deposit. Nature, 377:713-716.

Humphris, S.E., Herzig, P.M., Miller, D.J., et al., 1996. Proc. ODP, Init. Repts., 158: College Station, TX (Ocean Drilling Program).

James, R.H., and Elderfield, H., 1996. The chemistry of ore-forming fluids and mineral precipitation rates in an active hydrothermal sulphide deposit on the Mid-Atlantic Ridge. Geology, 24:1147-1150.

Janecky, D.R., and Seyfried, W.E., 1984. Formation of massive sulfide deposits on oceanic ridge crests: incremental reaction models for mixing between hydrothermal solutions and seawater. Geochim. Cosmochim. Acta, 48:2723-2738.

Kusakabe, M., and Chiba, H., 1983 Oxygen and sulfur isotope compositions of barite and anhydrite from the Fukazawa deposit, Japan. In Ohmoto, H., and Skinner, B.J. (Eds.), The Kuroko and Related Volcanogenic Massive Sulfide Deposits. Econ. Geol. Monogr. 5:292-301.

Lalou, C., Reyss, J.L., Brichet, E., Arnold, M., Thompson, G., Fouquet, Y., and Rona, P.A., 1993. New age data for Mid-Atlantic Ridge hydrothermal sites: TAG and Snakepit geochronology revisited. J. Geophys. Res., 98:9705-9713.

Lalou, C., Reyss, J.-L., Brichet, E., Rona, P.A., and Thompson, G., 1995. Hydrothermal activity on a $10^{5}$-year scale at a slow-spreading ridge, TAG hydrothermal field, Mid-Atlantic Ridge $26^{\circ}$ N. J. Geophys. Res., 100:17855-17862.

Lloyd, R.M., 1967. Oxygen-18 composition of oceanic sulfate. Science, 156:1228-1231

1968. Oxygen isotope behavior in sulfate-water system. J. Geophys. Res., 73:6099-6110.

Masuda, H., Chiba, H., Gamo, T., Fujioka K., and Nakamura, M., 1995. Distribution and chemical characteristics of hydrothermal alteration minerals recovered from the TAG active mound, MAR $26^{\circ} \mathrm{N}$. JAMSTEC J. Deep Sea Res., 11:111-124.

McGregor, B.A., Harrison, C.G.A., Lavelle, J.W., and Rona, P.A., 1977. Magnetic anomaly patterns on Mid-Atlantic Ridge crest at $26^{\circ} \mathrm{N}$. J. Geophys. Res., 82:231-238

Mills, R.A., and Elderfield, H., 1995. Rare earth element geochemistry of hydrothermal deposits from the active TAG mound, $26^{\circ} \mathrm{N}$ Mid-Atlantic Ridge. Geochim. Cosmochim. Acta, 59:3511-3524

Palmer, M.R., 1992. Controls over the chloride concentration of submarine hydrothermal vents: evidence from $\mathrm{Sr} / \mathrm{Ca}$ and ${ }^{87} \mathrm{Sr} /{ }^{86} \mathrm{Sr}$ ratios. Earth Planet. Sci. Lett., 109:37-46.

Pickthorn, W.J., and O'Neil, J.R., $1985 .{ }^{18} \mathrm{O}$ relations in alunite minerals: potential single-mineral thermometer. Geol. Soc. Am. Abstr. Progr., 17:7.

Prieto, M., Putnis, A., and Fernandez-Diaz, L., 1990. Factors controlling the kinetics of crystallization: supersaturation evolution in a porous medium. Application to barite crystallization. Geol. Mag., 127:485-495.

Putnis, A., Prieto, M., and Fernandez-Diaz, L., 1995. Fluid supersaturation and crystallization in porous media. Geol. Mag., 132:1-13.

Rona, P.A., Hannington, M.D., Raman, C.V., Thompson, G., Tivey, M.K., Humphris, S.E., Lalou, C., and Petersen, S., 1993. Active and relict seafloor hydrothermal mineralization at the TAG hydrothermal field, MidAtlantic Ridge. Econ. Geol., 88:1987-2013.

Rona, P.A., Klinkhammer, G., Nelson, T.A., Trefry, J.H., and Elderfield, H., 1986. Black smokers, massive sulfides and vent biota on the Mid-Atlantic Ridge. Nature, 321:33-37.

Rona, P.A., McGregor, B.A., Betzer, P.R., Bolger, G.W., and Krause, D.C., 1975. Anomalous water temperatures over Mid-Atlantic Ridge Crest at $26^{\circ}$ N. Deep-Sea Res. Part A, 22:611-618.

Shanks, W.C., III., Böhlke, J.K., Seal, R.R., II, 1995. Stable isotopes in midocean ridge hydrothermal systems: interactions between fluids, minerals, and organisms. In Humphris, S.E., Zierenberg, R.A., Mullineaux, L.S., Thompson, R.E. (Eds.), Seafloor Hydrothermal Systems: Physical,
Chemical, Biological, and Geological Interactions. Geophys. Monogr., 91:194-221.

Shikazono, N., and Holland, H.D., 1983. The partitioning of strontium between anhydrite and aqueous solutions from $150^{\circ}$ to $250^{\circ} \mathrm{C}$. In Ohmoto, H., and Skinner, B.J. (Eds.), The Kuroko and Related Volcanogenic Massive Sulfide Deposits. Econ. Geol. Monogr., 5:320-328.

Shikazono, N., Holland, H.D., and Quirk, R.F., 1983. Anhydrite in Kuroko deposits: mode of occurrence and depositional mechanisms. In Ohmoto, H., and Skinner, B.J. (Eds.), The Kuroko and Related Volcanogenic Massive Sulfide Deposits. Econ. Geol. Monogr., 5:329-344.

Sleep, N.H., 1991. Hydrothermal circulation, anhydrite precipitation, and thermal structure at Ridge axes. J. Geophys. Res., 96:2735-2387.

Teagle, D.A.H., Alt, J.C., Bach, W., Halliday, A.N., and Erzinger, J., 1996. Alteration of upper ocean crust in a ridge-flank hydrothermal upflow zone: mineral, chemical, and isotopic constraints from Hole 896A. In Alt, J.C., Kinoshita, H., Stokking, L.B., and Michael, P.J. (Eds.), Proc. ODP, Sci. Results, 148: College Station, TX (Ocean Drilling Program), 119150.

Teagle, D.A.H., Alt, J.C., and Halliday, A.N., 1995. Tracing the chemical evolution of hydrothermal fluids during recharge as recorded by anhydrite from Hole 504B. Eos, 76:709.

Thompson, G., Humphris, S.E., Schroeder, B., Sulanowsha, M., and Rona, P.A., 1988. Active vents and massive sulfides at $26^{\circ} \mathrm{N}$ (TAG) and $23^{\circ} \mathrm{N}$ (Snakepit) on the Mid-Atlantic Ridge. Can. Mineral., 26:697-711.

Tivey, M.K., 1995. Modeling chimney growth and associated fluid flow at seafloor hydrothermal vent sites. In Humphris, S.E., Zierenberg, R.A., Mullineaux, L.S., and Thomson, R.E. (Eds.), Seafloor Hydrothermal Systems: Physical, Chemical, Biological and Geological Interactions. Am. Geophys. Union, Geophys. Monogr., 91:158-177.

Tivey, M.K., Humphris, S.E., Thompson, G., Hannington, M.D., and Rona, P.A., 1995. Deducing patterns of fluid flow and mixing within the TAG active hydrothermal mound using mineralogical and geochemical data. $J$. Geophys. Res., 100:12527-12555.

Vidal, P., and Clauer, N., 1981. Pb and $\mathrm{Sr}$ isotopic systematics of some basalts and sulphides from the East Pacific Rise at $21^{\circ} \mathrm{N}$ (Project RITA). Earth Planet. Sci. Lett., 55:237-246.

Von Damm, K.L., 1995. Controls on the chemistry and temporal variability of seafloor hydrothermal fluids. In Humphris, S.E., Zierenberg, R.A., Mullineaux, L.S., and Thomson, R.E. (Eds.), Seafloor Hydrothermal Systems: Physical, Chemical, Biological, and Geological Interactions. Am. Geophys. Union, 91:222-247.

Von Damm, K.L., Edmond, J.M., Grant, B., Measures, C.I., Walden, B., and Weiss, R.F., 1985. Chemistry of submarine hydrothermal solutions at $21^{\circ}$ N, East Pacific Rise. Geochim. Cosmochim. Acta, 49:2197-2220.

Watanabe, M., and Sakai, H., 1983. Stable isotope geochemistry of sulfates from the Neogene ore deposits in the Green Tuff region, Japan. In Ohmoto, H., and Skinner, B.J. (Eds.), The Kuroko and Related Volcanogenic Massive Sulfide Deposits. Econ. Geol. Monogr., 5:282-291.

Woodruff, L.G., and Shanks, W.C., 1988. Sulfur isotope study of chimney minerals and hydrothermal fluids from $21^{\circ} \mathrm{N}$, East Pacific Rise: hydrothermal sulfur sources and disequilibrium sulfate reduction. J. Geophys. Res., 93:4562-4572.

Date of initial receipt: 3 June 1996

Date of acceptance: 10 January 1997

Ms 158SR-223 